Second revised version for JLEO: July 19, 2001

\title{
The Role of Political Parties in the Organization of Congress"
}

\author{
John R. Boyce* and Diane P. Bischak** \\ *Department of Economics \\ University of Calgary \\ 2500 University Dr. NW \\ Calgary, Alberta T2N 1N4 \\ CANADA \\ boyce@ucalgary.ca \\ (403) 2205860 \\ **Operations Management Area \\ Faculty of Management \\ 2500 University Dr. NW \\ Calgary, Alberta T2N 1N4 \\ CANADA \\ dbischak@mgmt.ucalgary.ca
}

(403) 2203368

July 2001

\begin{abstract}
Theory and evidence on party competition in the U. S. Congress and its effect on the composition of committees is considered. Parties compete over multiple policy dimensions by allocating party members to committees. The leadership of each party simultaneously and non-cooperatively selects its committees' membership in order to maximize the joint utility of its members, taking into account how the committee membership affects the legislation adopted by the legislature. Parties are constrained both by institutional rules and by the heterogeneity of party members' preferences in their allocation of party members across committees. These restrictions mean that to gain an edge in one policy dimension, a party must give ground elsewhere. Interest group ratings from the U.S. House of Representatives provide evidence that the parties stack committees in a manner consistent with the predictions of the theoretical model. Tests of alternative hypotheses reveal that these hypotheses explain no more than half the committees in the U. S. Congress, while the party competition hypothesis is consistent with the overall structure of the committees.
\end{abstract}

\footnotetext{
\# This paper has benefited from the comments of seminar participants at the University of Auckland, Montana State University, and the 1998 Public Choice Society meetings. We also thank Ron Johnson, Rich Sicotte, Associate editor Mathew McCubbins, and three referees for helpful comments. All errors are our own.
} 


\section{The Role of Political Parties in the Organization of Congress}

Abstract: Theory and evidence on political party competition in the U. S. Congress and its effect on the compositions of committees is considered. Parties compete over multiple policy dimensions by allocating party members to committees. The leadership of each party simultaneously and non-cooperatively selects its committees' membership in order to maximize the joint utility of its members, taking into account how the committee membership affects the legislation adopted by the legislature. Parties are constrained both by institutional rules and by the heterogeneity of party members' preferences in their allocation of members across committees. These restrictions mean that to gain an edge in one policy dimension, $a$ party must give ground elsewhere. Interest group ratings from the U.S. House of Representatives provide evidence that the parties stack of committees in a manner consistent with the predictions of the theoretical model. Indeed, tests of alternative hypotheses reveal that these hypotheses explain at best only half of the committees in the U.S. Congress, while the party competition hypothesis is consistent with the overall structure of the committees.

\section{Introduction}

In the U. S. system of government, much of the power to influence legislation that in parliamentary systems of government is held by political parties is delegated to Congressional committees. As a result, the U. S. legislative system exhibits less party cohesion on floor votes than occurs in Britain, Canada and elsewhere. Parties do, however, appear to be an important feature of both systems. Indeed, party control of the legislature seems no less important an issue U. S. elections than under parliamentary systems. What role do political parties play in the organization of the U. S. Congress?

Recent theories on the organization of the Congress downplay the role of political parties and instead focus on the committee system. ${ }^{1}$ In the "preference outlier hypothesis," legislative committees are populated by those legislators most interested in the policies over which the committee has authority. In this way, "advocacy is concentrated and opposition is diluted" (Niskanen 1971, p. 139). ${ }^{2}$ Committees populated by high-demand legislators can block legislation they dislike, enabling them to enforce logrolling agreements to pass legislation their members prefer (Weingast and Marshall 1988). ${ }^{3}$ This in

\footnotetext{
${ }^{1}$ Important exceptions include Rhode (1994) and Aldrich (1994). See also Krehbiel and Meirowitz (1999).

${ }^{2}$ See also Benson $(1981,1983)$ and Adler and Lapinski (1997).

${ }^{3}$ A comprehensive review of this debate, along with the positions of the major proponents and comments and criticisms, is found in the May, August and November 1994 issues of Legislative Studies Quarterly. See also Groseclose (1994a, 1994b) and Adler
} 
turn helps the legislators in their quest for reelection, which, it is argued, is the purpose of the committee system in Congress. The party system plays no role in that argument.

The role of political parties is also downplayed in the "informative committees hypothesis" (Gilligan and Krehbiel 1987, 1989, 1990, 1994, and Krehbiel 1990, 1991). ${ }^{4}$ Under this hypothesis, committees provide information to the floor about the (uncertain) effects of policy in order to "specialize and to share the benefits of specialization" (Krehbiel 1990, p. 531). In contrast to the preference outlier hypothesis, this hypothesis predicts that committees will be populated with members whose preferences do not differ systematically from the floor and, because higher variance yields greater information, that committees will be at least as heterogeneous as the entire floor. ${ }^{5}$

The "representative majority party hypothesis" (Cox and McCubbins 1993) explicitly grants a role to the majority (but not the minority) political party. Since the parties vote party line on the votes to adopt the committee structure (Cox and McCubbins 1993, p. 2), the majority party can stack the committee selection process in its favor. Thus, under the representative majority party hypothesis hypothesis, committees will reflect the preferences of the majority party. ${ }^{6}$

Given that the empirical predictions of the three hypotheses are quite different, it is surprising to find that there is still controversy. The first systematic empirical evidence (Weingast and Marshall 1988) used interest group ratings to look at the composition of a selection of committees and subcommittees in the U.S. House of Representatives. ${ }^{7}$ This evidence, purporting to support the preference outlier hypothesis, was challenged by several authors (Krehbiel 1990, 1991 and Cox and McCubbins 1993, among others), ${ }^{8}$

and Lapinski (1997) for brief reviews of this debate.

${ }^{4}$ See also Epstein (1997) and Saving (1997) on the topic of how legislatures deal with the information asymmetry between committees and the floor.

${ }^{5}$ This interpretation may be controversial, but it is consistent with Krehbiel's own interpretation of the statistical tests. Krehbiel (1991, p. 150) argues "support for the informational perspective was found in ... the prevalence of heterogeneous committees." Krehbiel defines a heterogeneous committee as having a variance greater than or equal to the variance from the floor (excluding the committee). We conduct this same test. However, a referee notes that this is inconsistent with the Gilligan-Krehbiel signaling games as in Gilligan and Krehbiel (1990, p. 417).

${ }^{6}$ This is the interpretation that Krehbiel (1991, pp. 125-6, n. 22) adopts regarding the representative majority hypothesis.

${ }^{7}$ Groseclose (1994b) provides a nice summary of earlier evidence on the preference outlier hypothesis.

${ }^{8}$ Krehbiel concludes "the results ... force us to entertain the possibility that the standard preference outlier story is a stylized fiction" (1990, p. 159). Weingast and Marshall's empirical evidence on the preference outlier hypothesis has been shown to be invalid (Groseclose 1994a). Most other recent empirical evidence has rejected the preference outlier hypothesis except in a few committees in the U. S. House (Cox and McCubbins 1993, Mooney and Duval 1993, Groseclose 1994b), although Londregan 
whose models, have in turn received criticism (e.g., Hall and Grofman 1990, Groseclose 1994b, Londregan and Snyder 1994, Rhode 1994, Epstein 1997, Saving 1997, and Adler and Lapinski 1997).

This paper presents and tests a model that combines elements of the preference outlier hypothesis (Weingast and Marshall 1988) with elements of the representative majority party hypothesis (Cox and McCubbins 1993). We follow the latter in placing political parties at the center of our analysis, but we are not convinced that the majority party has free rein in setting up the legislature. Although the majority party has historically been able to enforce party line voting in setting up the structure for each Congress, the majority party, at best, controls only the number of minority party members on each committee-it cannot control the identity of the minority party members on each committee. ${ }^{9}$ The majority party is also constrained by heterogeneity within its own party, which provides an opportunity for the (also heterogeneous) minority party to influence the structure of the committee system. Thus in our view both parties actively participate in the committee allocation process.

In our model, each committee has the exclusive right to formulate policies within its domain, although changes to policies must be able to survive challenges on the floor by logrolling, gate-keeping, or simply being satisfactory to the floor. Since they vary in their policy interests, party members compete for committee memberships. Unlike Weingast and Marshall (1988), who argue that parties grant committee memberships to the highest bidders, we assume that parties make committee membership decisions with the objective of maximizing a social welfare function of the utilities of their members, given that, once on a committee, members act to maximize their own utility. ${ }^{10}$

In their allocation of members across committees, parties face many institutional constraints: members are restricted to a maximum number of committee assignments, memberships on committees are

and Snyder (1994) and Adler and Lapinski (1997) found evidence in support of the preference outlier hypothesis. See also Epstein (1997) and Saving (1997) for a criticism of the informative committees hypothesis.

${ }^{9}$ Phillipson (1992) has examined a model in which the relative size of committees is endogenous. We ignore this endogeneity in the model below.

${ }^{10}$ This is an important distinction, because Weingast and Marshall make an implicit assumption that the mechanism whereby members compete for committees will result in an efficient outcome for the party. As with all pricing systems, this mechanism will result in maximizing the party's welfare only if the memberships of each committee do not impose costs on non-members. We argue that it is because of this type of externality that the party will not always grant committee memberships to its members who value them the highest. 
treated as quasi-property rights based on seniority, and party membership on each committee must be (roughly) in proportion to its membership on the floor. ${ }^{11}$ A main feature of our model is the observation that these constraints imply that committee assignments are not independent of one another. For example, if each member sits on only one committee and there are only two committees, then if committee $A$ is stacked more conservatively than the floor, committee $B$ must be more liberal than the floor, since it is committee A's complement. This would have little consequence if each party were comprised of homogeneous members. The political parties clearly identify with some policies more than othersDemocrats are generally pro-labor, pro-environment, and for more social spending, while Republicans are for free trade, for less regulation and lower taxes, and against abortion. While these distinctions are important (e.g., Philipson 1992), they mask the heterogeneity that exists within each party. The Republican party's positions on abortion and gun control run counter to its "liberal wing," and the Democratic party's position on government expansion runs counter to the interests of its conservative Southern wing. We explicitly consider this heterogeneity.

Furthermore, the interests of the two parties are not always at odds. Members of both parties may benefit by, for example, being perceived as "tough on crime," by increased government spending on public works, or by endorsing a strong military defense. Where there are major policy differences between the parties, committees dealing with the issues in these policy areas will tend to be polarized or confrontational, but in policy areas that are more important to one of the parties, committees will tend to be more lopsided than the floor, and it will appear that the parties accommodate one another. Thus, not all committees are likely to be preference outliers, and those that are may be preference outliers in different directions.

The paper is organized as follows. Section 2 presents empirical evidence concerning the distributions of party members' voting preferences in the U. S. House of Representatives. Section 3 develops the

\footnotetext{
${ }^{11}$ In Philipson (1992) each party prefers a different policy, and all members of each party prefer the same policy. He argues that party proportions on committees will equal the floor proportions because this maximizes the power of each committee member (e.g., a member's presence is most likely to affect the outcome when committees are formed in this fashion). Because party memberships are heterogeneous in our model, we focus on the question of which members will go on which committees. This is not an issue when all members of the same party have the same preferences.
} 
theoretical model of how each party allocates its members to committees, given competition from the other party and given institutional constraints on committee allocations. Section 4 presents a direct test of our hypothesis based on the comparative statics properties of the committee assignment equilibrium. Section 5 uses a re-sampling method that explicitly incorporates institutional restrictions on committee membership allocations to reexamine tests of the alternative hypotheses in the literature. Section 6 concludes the paper with a discussion of the model and the results.

\section{Party Heterogeneity and Committee Allocations}

The data we analyze covers the $97^{\text {th }}-102^{\text {nd }}$ Congresses (1981-1992). Throughout this period, the U.S. House of Representatives was controlled by the Democratic Party, and the Democratic majority during this period ranged from $243(55.9 \%)$ to $269(61.8 \%)$ of the 435 members. A number of interest groups maintained ratings indices for each member, based on floor votes (i.e., votes in which all members could vote) selected by the interest group. ${ }^{12}$ The range of each rating index is from 0 to 100 , with a congressman getting a 0 if he votes against the wishes of the interest group on each of the votes selected for the index and a 100 if he votes with the group one hundred per cent of the time. The indices used in the analysis and the issues that the Congressmen are rated on are contained in Table $1 .{ }^{13}$ Table 1 presents the median ratings in the U. S. House for the whole floor and for each party individually for the $97^{\text {th }}-$ $102^{\text {nd }}$ Congresses for eight different interest group ratings. Democrats score high on the ADA, COPE, LCV, CFA and ACLU rating scales, and Republicans score high on the NSI, NTU and COC rating scales. $^{14}$

\footnotetext{
${ }^{12}$ The ratings used in the analysis include the Americans for Democratic Action (ADA), American Civil Liberties Union (ACLU), Consumer Federation of America (CFA), Chamber of Commerce of the United States (COC), the AFL-CIO Committee on Political Education (COPE), the League of Conservation Voters (LCV), the National Security Index of the American Security Council (NSI), and the National Taxpayers Union (NTU). Due to data limitations, Ralph Nader's Public Citizen (PC) index is used during the $97^{\text {th }}$ Congress in lieu of the ACLU index; the National Association of Business (NAB) index is used during the $98^{\text {th }}$ Congress in lieu of the COC index; and the National Tax Limitation Committee (NTLC) index is used for the $101^{\text {st }}$ and $102^{\text {nd }}$ Congresses in lieu of the NTU index. All data is from the Almanac of American Politics (Barone et al., various years).

${ }^{13}$ The ratings used for each Congress are the ratings the congressman received in the even numbered year of the previous Congress. Thus newly elected congressmen are omitted from the analysis. We also omit party leaders, since they serve on no committees.

${ }^{14}$ Evident in Table 1 are the difficulties with using this sort of data. Many ratings have very little dispersion for one of the parties (e.g., the median Republican NSI rating is 100 for each Congress).
} 
The parties appear quite different from one another if judged by the median ratings alone. While there are clear differences in measures of central tendency between the distributions of the two parties, each party's membership is itself quite heterogeneous. A more complete picture is given by Figure 1, which shows histograms of the ratings for each party for the $102^{\text {nd }}$ Congress (1991-92). (Similar evidence can be presented for each of the Congresses in the sample.) The party distributions clearly overlap one another. Each party's members also tend to be distributed over most of the range of possible values. Indeed, "moderate" Democrats (Republicans) are more conservative (more liberal) than the median member of the other party. In addition, the "extremists" tail of each party (e.g., the left tail of the Democrats and the right tail of the Republicans on a liberal rating such as $\mathrm{ADA}$ ) is quite thick. This means that if either party switches an extremist member with a moderate member (e.g., if the Democrats replace one of its liberal members on a committee with a conservative member), the party median — and perhaps the committee median-changes.

There also exist institutional rules in the House restricting the composition of committees and the number of committees on which a member can serve. Over the $96^{\text {th }}$ to $102^{\text {nd }}$ Congresses $(1979-1992)$ Democratic members served on slightly more committees (1.83 committees per Democratic member versus 1.72 committees per Republican member). However, when we regressed the Democratic percentage on each individual committee on the House percentage of Democrats, controlling for individual committees and including linear and quadratic trend variables, with three exceptions, we could not reject the null hypothesis that the committees' Democratic shares are proportional to the House. ${ }^{15}$ The three exceptions are Rules (more heavily Democratic) and House Administration and Standards of Official Conduct (less heavily Democratic). ${ }^{16}$ The House Administration and Standards of Official Conduct Committees are intentionally bi-partisan, while the Rules Committee is intentionally partisan.

\footnotetext{
15 These results are similar to those of Philipson (1992). The House Democratic percentage variable coefficient is 0.717 (with a standard error of 0.176). This suggests that the Democrats did not engage in a tyranny of the majority in monopolizing committees. However, the null hypothesis that this coefficient is unity can not be rejected (p-value of 0.107). The intercept is 0.185 (s.e. 0.11), so the null hypothesis that the intercept is zero could not be rejected (p-value of 0.094). Neither of the trend variables are significant. The adjusted R-squared is 0.388 . The regression is based on 153 observations (Ways and Means was omitted from the 1979-80 data).

${ }^{16}$ The regression coefficient for the House Administration Committee is -0.138 (standard error of 0.038); the coefficient for the
} 
Our argument is that if a party stacks one committee, it is forced to give ground on another committee. Parties may try to get around this restriction by placing more extreme members on a larger number of committees. This is tested by regressing a member's number of committee assignments on the member's ADA rating (for Democrats) and the ACU rating (for Republicans), controlling for the number of years served in Congress, and including dummy variables for each Congress. ${ }^{17}$ The regression results are (the Congress dummy variables are not reported; $t$-statistics are given in parentheses):

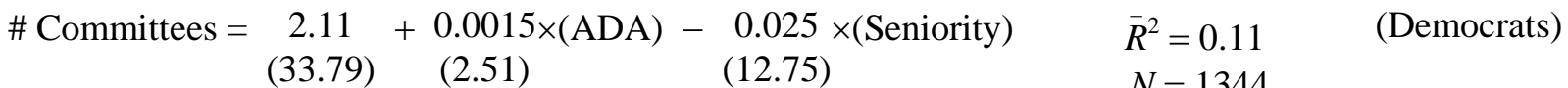

$$
\begin{aligned}
& \text { \# Committees }=\begin{array}{cccc}
2.04 & -\underset{(22.95)}{0} \underset{(0.92)}{0.0008 \times(\mathrm{ACU})}-\underset{(3.62)}{0.011 \times(\text { Seniority })} & \bar{R}^{2}=0.02
\end{array} \quad \text { (Republicans) }
\end{aligned}
$$

Thus, Democrats tend to grant additional committee assignments for members that are more liberal, but Republicans do not for members that are more conservative. However, even for Democrats, the economic effect is negligible: a fifty-point increase in a Democratic member's ADA rating results in an extra committee assignment for only about one in thirteen members. The regressions also indicate that the number of committee assignments decrease in both parties as seniority increases, which supports the hypothesis that there are gains to specialization in the legislature.

\section{Theory: Party Competition and Committee Assignments}

The model we present is motivated by the above empirical observations. In particular, party membership on committees is restricted to equal the party proportion in the House, members are restricted to a limited number of committees, and each party is heterogeneous. We also follow the literature (e.g., Weingast 1989, and Krehbiel and Meirowitz 1999) by assuming that once the committees are formed, the amendment process is fixed, with committees proposing a bill $b$ to alter the status quo $q$, the majority party offering an amendment $a$, and the committees responding with a perfecting amendment $p$. Our

Standards and Official Conduct Committee is -0.248 (standard error of 0.038), and the coefficient for the Rules Committee is 0.082 (standard error of 0.038 ). 
contribution to this literature is that we explicitly model how the committees are formed.

\section{A. The Model.}

The legislature is comprised of two parties. Proportion $k_{M}>1 / 2$ belong to the majority party, $M$, and proportion $k_{m}=1-k_{M}<1 / 2$ belong to the minority party, $m$. The legislature considers two issues, $x$ and $y$, where $\{x, y\} \subset P$, the set of possible policies. Let $f_{i}(x, y)$ denote the density of the members of party $i$ whose ideal points are $\{x, y\}$. Thus, $\iint_{P} f_{i}(x, y) d x d y=k_{i}, i=m, M$.

Committees $X$ and $Y$ act as gatekeepers for policies $x$ and $y$, respectively. Thus, each committee can prevent consideration of a bill to change the status quo, $q \equiv\left\{x_{q}, y_{q}\right\}$, for their particular issue. However, if the committees wish to alter the status quo, they must obtain the support of the majority of the legislature. The party's allocations to each committee are constrained by the institutional arrangement that each committee is comprised of $k_{M} / 2$ majority party members and $k_{m} / 2$ minority party members, and each party member is allocated to a single committee, $X$ or $Y .^{18}$ Let $\chi_{i}$ denote the set of feasible committee allocations for party $i=M, m$. So long as the party's distributions of preferences overlap, each party can affect the committee medians through its choice of committee assignments. In the case where the members of each party are distributed on a single dimension (i.e., a left-right scale), the institutional restriction $\chi_{i}$ requires that if party $i$ stacks committee $X$ to the right, then it must stack committee $Y$ to the left. Similar restrictions exist even when the parties are distributed across more than one dimension.

The parties allocate their members to committees to maximize the weighted sum of the utility of the party membership of the resulting policies, taking the other party's allocation as given. The party's committee allocations are denoted as $C_{i} \in \chi_{i}, i=m, M$. Together, these form committees with composition $\left\{C_{x}, C_{y}\right\}$.

Let $p^{*}=\left\{x^{*}, y^{*}\right\}$ denote the equilibrium policy. We assume that the utility of a member of party $i$ whose preferred policy is $\{x, y\}$ is given by

\footnotetext{
${ }^{17}$ The results are qualitatively the same when the ADA or the ACU is used for each party.

${ }^{18}$ More generally, the distribution of party members could be renormalized to allow for a mass of greater than one for committee memberships. Call this new distribution $\phi_{i}(x, y)$, where $=\iint \phi_{i}(x, y) d y d x>k_{i}$. Then all of the results below could be established
} 


$$
U^{i}\left(p^{*} \mid x, y\right)=u_{i}-\alpha_{i}\left(x-x^{*}\right)^{2}-\beta_{i}\left(y-y^{*}\right)^{2}, \quad i=M, m .
$$

The parameters $\alpha_{i}$ and $\beta_{i}$ indicate party $i$ 's relative preference intensity for the policies $x$ and $y$, respectively, and $u_{i}>0$ is the utility the party member obtains if her preferred policy is adopted. Assuming that the density of preferences, $f_{i}(x, y)$, is independent across dimensions (i.e., $f_{i}(x, y)=$ $g_{i}(x) h_{i}(y)$ for some density functions $g$ and $\left.h\right)$, party $i$ 's welfare function is: ${ }^{19}$

$$
U_{i}\left(p^{*}\right)=k_{i}\left[\bar{u}_{i}-\alpha_{i}\left(\bar{x}_{i}-x^{*}\right)^{2}-\beta_{i}\left(\bar{y}_{i}-y^{*}\right)^{2}\right], \quad i=M, m,
$$

where $\bar{x}_{i}$ and $\bar{y}_{i}$ are party $i$ 's mean preferred policies in $x$ and $y$, and $\bar{u}_{i}$ is a constant. These form the ideal points for party $i$. The party shares $k_{i}$ appear because we are summing across all party members. The effect of the preference parameters $\alpha_{i}$ and $\beta_{i}$ is seen by considering the indifference curves for each party:

$$
\left.\frac{d y}{d x}\right|_{d U_{i}=0}=-\frac{\alpha_{i}\left(\bar{x}_{i}-x\right)}{\beta_{i}\left(\bar{y}_{i}-y\right)}, \quad i=M, m \text {. }
$$

When $\alpha_{i}=\beta_{i}$, the indifference curves are circles, and when $\alpha_{i} \neq \beta_{i}$, the indifference curves are ellipses. As $\alpha_{i} \rightarrow 0$, party $i$ 's indifference curves in $x-y$ space become perfectly horizontal so only policies in the $y$ direction matter, and as $\beta_{i} \rightarrow 0$, they become perfectly vertical, so only $x$ policies matter.

As each committee is responsible only for its own issue (i.e., $x$ for $X$ and $y$ for $Y$ ), the committees' weighted preferences, $U_{C}$, depend upon the respective committees' preferences in each dimension. Let the (combined) committees' preferred policy be $C=\left\{\hat{x}_{C}, \hat{y}_{C}\right\}$, where $\hat{x}_{C}$ is the median in dimension $x$ for committee $X$ and $\hat{y}_{C}$ is the median in dimension $y$ for committee $Y$.

The parties can either accommodate one another, by stacking different committees with the extremists from their parties (so the moderates of one party are with the extremists of the other party, and visa

using $\phi_{i}$ rather than $f_{i}$.

${ }^{19}$ Equation (1) is derived by integrating the mass-weighted utility of the party for a given policy $\left\{x^{*}, y^{*}\right\}$ $U_{i}\left(p^{*}\right)=\iint f_{i}(x, y) U^{i}\left(p^{*} \mid x, y\right) d y d x$,

where $U^{i}\left(p^{*} \mid x, y\right)=u_{i}-\alpha_{i}\left(x-x^{*}\right)^{2}-\beta_{i}\left(y-y^{*}\right)^{2}$ is the utility of a member whose preferred policy is $\{x, y\}$, and $f_{i}(x, y)=$ $g_{i}(x) h_{i}(y)$ is the party distribution of members over the set of preferred policies. The constant $\bar{u}_{i}$ is a function of the $u_{i}$ and the variance of the party distributions in $x$ and $y$. In the event that the parties care about the median member, then the mean would be replaced with the median in equation (1), and the $k_{i}$ terms would not appear. If the preferences are correlated across the $x-y$ dimension, there would be an additional interaction term of the form $k_{i} \alpha_{i} \beta_{i}\left(\bar{x}_{i}-p_{x}\right)\left(\bar{y}_{i}-p_{y}\right) \operatorname{cov}(x, y)$ in $(1)$. 
versa), or the parties can confront one another, by stacking one committee with the extremists from both parties (implying the other committee is filled with moderates from both parties).

Let the committee memberships be chosen using an accommodation strategy, with committee $X$ having preferences closer to the minority party and committee $Y$ having preferences closer to the majority party. Suppose the committees do not cooperate on the floor. Then under the amendment process outlined above, combined with the unidimensional issue space for each committee and the overlapping distributions, if the committees do not cooperate, committee $X$ obtains policy $x^{*}$ close to $\hat{x}_{C}$, since both the committee and the minority party—who has the amendment rights—are on the same side of the median voter in the legislature. However, any policy committee $Y$ proposes is amended by the minority party such that the equilibrium policy is $y^{*}=\hat{y}_{f}$, the floor median. Thus, committee $X$ gets its way but $Y$ does not. However, the majority party can obtain policy $\left\{\hat{x}_{f}, \hat{y}_{f}\right\}$ if it counters actions of the minority so that each committee is homogeneous (denoted as ' $H$ '), i.e., where each committee has preferences $\hat{x}_{C}=\hat{x}_{f}$ and $\hat{y}_{C}$ $=\hat{y}_{f}$. Therefore, the majority party wields a credible threat to force the minority party to cooperate.

In contrast, suppose each party chooses a strategy of confrontation on one committee. The confrontation committee will be composed of bipolar, but the bipolar complement committee will be composed of centrist members. In this case, it does not matter whether or not the committees cooperate on the floor, since the bipolar complement committee will roughly reflect the floor and the bipolar committee will either reflect the floor or be unsuccessful at the floor level.

Thus, we assume the committees cooperate, in effect maximizing

$$
U_{C}\left(p^{*}\right)=\bar{u}_{C}-\alpha_{C}\left(\bar{x}_{C}-x^{*}\right)^{2}-\beta_{C}\left(\bar{y}_{C}-y^{*}\right)^{2}
$$

where $\alpha_{C}=\varphi_{x}\left(C_{M}, C_{m}, k_{M}\right)$ and $\beta_{C}=\varphi_{y}\left(C_{M}, C_{m}, k_{M}\right)$ are the preferences for committee $X$ and committee $Y$ in their respective dimensions, where the weighting functions $\varphi_{x}$ and $\varphi_{y}$ each have non-negative first derivatives in the committee allocations for each party.

Once the parties have selected the committee memberships $C$, the committees are formed and the policy recommendations are sent to the floor, where the amendment procedure $b$ - $a-p$ is followed. 
Following Weingast (1989) and Krehbiel and Meirowitz (1999), we assume the floor votes occur with only three voters: the majority party $M$ (with ideal point $\left\{\bar{x}_{M}, \bar{y}_{M}\right\}$ ), the minority party $m$ (with ideal point $\left\{\bar{x}_{m}, \bar{y}_{m}\right\}$ ), and the committees $C$ (with ideal point $\left\{\hat{x}_{C}, \hat{y}_{C}\right\}$ ). However, unlike Weingast (1989), where the preferences of the committees are given exogenously, here the committees $C$ preferences depend upon how the parties allocate their members to the two committees $X$ and $Y$. The equilibrium concept is that of sub-game perfection, with each voter and each party leadership acting strategically.

The game is played as follows. First, the parties choose the committee allocations $C_{M}$ and $C_{m}$, simultaneously and non-cooperatively, yielding committee preferences $C$. Once the committees are formed, the floor voting occurs according to an amendment procedure wherein the committees send bill $b$ $\equiv\left\{x_{b}, y_{b}\right\}$ to the floor, the minority party offers an amendment $a \equiv\left\{x_{a}, y_{a}\right\}$, and the committees reply with a perfecting amendment $p \equiv\left\{x_{p}, y_{p}\right\}$. The bill $b$ must be capable of beating the status quo $q$. Thus $b \in$ $W_{C}(q)$, the win-set for $q$ (the set of policies that garner at least a majority vote against $q$ ). The subscript ' $C$ ' indicates that the win-set depends upon the committees composition $C$. The amendment $a$ must be able to beat both the bill $b$ and the status quo $q$, i.e., $a \in W_{C}(q) \cap W_{C}(b)$. Finally, the perfecting amendment $p$ must be able to beat $a$, $b$, and $q$, i.e., $p \in W_{C}(q) \cap W_{C}(b) \cap W_{C}(a)$. In equilibrium, the policy $p^{*}$ equals the perfecting amendment $p$.

The game is analyzed by backwards induction. In the final stage of the game, the committees choose the perfecting amendment $p$ to maximize $U_{C}$, taking as given the committees preferences $C$, the status quo $q$, the committee bill $b$, and the minority party's amendment to the committee bill, $a$ :

$$
p^{*}(C, q, b, a)=\underset{p}{\operatorname{argmax}} U_{C}(p), \text { subject to } p \in W_{C}(q) \cap W_{C}(b) \cap W_{C}(a) .
$$

The minority party chooses the amendment $a$ to maximize its own utility, taking as given the committee preferences, the status quo, the committee bill, and the equilibrium perfecting amendment $p^{*}$ : 


$$
a^{*}(C, q, b)=\operatorname{argmax} U_{m}\left(p^{*}(C, q, b, a)\right), \quad \text { s.t. } a \in W_{C}(q) \cap W_{C}(b) .
$$

The committee chooses the bill $b$ to maximize its utility, taking as given the committee preferences, the status quo, and the equilibrium behavior of the committee in choosing its perfecting amendment $p^{*}$ and the equilibrium behavior of the minority party $m$ in choosing its amendment $a^{*}$ :

$$
b^{*}(C, q)=\underset{b}{\operatorname{argmax}} U_{C}\left(p^{*}\left(C, q, b, a^{*}(C, q, b)\right)\right), \quad \text { s.t. } \quad b \in W_{C}(q) .
$$

Finally, the parties choose $C_{i}, i=m, M$, to maximize their own utilities taking $C_{-i}{ }^{*}$ as given:

$$
C_{i}^{*}=\underset{C_{i}}{\operatorname{argmax}} U_{i}\left(p^{*}\left(C, q, b^{*}(C, q), a^{*}\left(C, q, b^{*}(C, q)\right)\right)\right), \text { s.t. } C_{i} \in \chi_{i}, i=M, m .
$$

Following Weingast (1989), Figure 2 illustrates how a "structure induced equilibrium" is derived for a given committee ideal point $C$, a given status quo $q$, and the amendment procedure described above. In Figure 2, the status quo is outside the Pareto Set $P S_{C}$ (the interior of the points $M, m$, and $C$ ). The committees' objective is to maximize $U_{C}$ subject to majority rule and the amendment process.

Bill $b \in W_{C}(q)$ offered by the committees is a compromise between the preferred policy of the majority $M$ and the committees $C$. The win-set $W_{C}(q) \cap W_{C}(b)$ has two subsets: one with winning coalition $(M, m)$ and one with winning coalition $(m, C)$. Party $m$ chooses amendment $a$ in the latter subset of $W_{C}(q) \cap W_{C}(b)$ to restrict the perfecting amendment $p$ offered by the committees afterwards to the subset of $W_{C}(q) \cap W_{C}(b) \cap W_{C}(a)$ that contains $p$ rather than the other subset that contains the point $E$. In this way the minority party assures that it will attain the highest possible utility at the end of the game. Moving back one step, bill $b$ is chosen to make $p^{*}$ as close to $C$ as possible. As the reader can demonstrate, if bill $b$ were chosen closer to $M$ (say at $\hat{b}$ ), then the corresponding $\hat{a}$ (not shown) would be chosen on the boundary of $W_{C}(q) \cap W_{C}(\hat{b})$ in the lens containing $H$, making $C$ worse off. Similarly, if $C$ chooses $b$ closer to $C$ (say at $\tilde{b}$ ), then it becomes possible for $m$ to choose the corresponding $\tilde{a}$ (not shown) 
in the uppermost subset of $W_{C}(q) \cap W_{C}(\tilde{b})$, making $C$ worse off.

The committees' right to propose bills gives the committees the ability to play the two parties off one another. In equilibrium, the perfecting amendment is adopted with the support of the committees $C$ and the minority party $m$. This occurs because the minority party has the right to offer amendments to the bill $b$. By forming a coalition with the majority party on bill $b$, the committees ensure that the amendmentperfecting amendment process moves the bill closer to the committees' preferred position. If the bill $b$ coalition was formed with the minority party, the amendment offered by the minority party would move the bill even closer towards $m$ 's preferred position and away from the committees' preferred position.

Figure 3 shows how the equilibrium is obtained for $q \in P S_{C}$. In this case, the committees $C$ chooses $b$ such that the minority party $m$ has no amendment in the subset of $W_{C}(q)$ closest to $m$ (i.e., the subset of $W_{C}(q)$ with winning coalition $\left.(m, C)\right)$ that beats $b ; C$ can do better by forcing the amendment $a$ into the subset of $W_{C}(q)$ with winning coalition $(M, C)$. As in Figure 2, the amendment $a$ is chosen such that the perfecting amendment $p$ will be chosen in the subset of $W_{C}(q) \cap W_{C}(b) \cap W_{C}(a)$ that is closest to $m$ (i.e., $C$ prefers $p$ to point $F$, the best it can do in the subset of $W_{C}(q) \cap W_{C}(b) \cap W_{C}(a)$ closest to $\left.M\right)$. The winning coalition for the policy $p$ is again $(m, C)$, the minority party and the committees.

In Figures 2 and 3, the non-homogeneous committees position $C$ is taken as given. However, suppose the committees are homogeneous. In this case, the committees' ideal point is located at the points labelled $H$ in Figures 2 and 3. The Pareto set $P S_{H}$ is simply the line connecting $m, H$, and $M$. More importantly, if $\alpha_{i}=\beta_{i}$ for each party, then when committees $H$ propose bill $b^{*}=H$, that bill cannot be amended (i.e., $W_{H}(H)=\varnothing$ when the parties' indifference curves are circles). The equilibrium policy is thus $p^{*}(H)=H{ }^{20}$ In Figures 2 and 3, both parties prefer $p^{*}(H)=H$ to $p^{*}(C)=p$. Thus, if each party has similar intensity preferences over the two policies, there is no room for either party to improve its welfare by stacking the committees, so each party's committee delegation is representative of the party. Indeed, if one party did desire to make the committee different from the floor, the other party would improve its own welfare by

\footnotetext{
${ }^{20}$ Whenever the parties' indifference curves are elliptical it will occur that the amendment process may lead one away from $H$.
} 
pushing the committees back towards the floor means $H$, that is to stack the committee in the opposite direction.

\section{B. Accommodation on Committee Assignments.}

Next, we show that if the parties have preferences for different policies, the committees will appear as classical committee outliers - and outliers in opposite directions will occur. Since the parties stack each committee in the same direction, we call this outcome accommodation. Figure 4 considers the case where the parties each care only about one of the policies, e.g., $\alpha_{M}=\beta_{m}=1$ and $\beta_{M}=\alpha_{m}=0$. Thus, each parties' preferences are lexicographic, with the minority party preferring any policy with $y=\bar{y}_{m}$ and the majority party preferring any policy with $x=\bar{x}_{M}$. Given these preferences, one would expect gains from trade by stacking the committees, and Figure 4 shows that this is the case. Suppose the committees are homogeneous, so the committees' ideal points are at $H$. By choosing bill $b_{H}=H$ (with win-set $W_{H}(H)$ in the southeast quadrant from $H$ ), the committees force the minority party to offer an amendment such as $a_{H}$ $=\left\{\bar{x}_{M}, \bar{y}_{m}\right\}$. The $W_{H}(q) \cap W_{H}\left(b_{H}\right) \cap W_{H}\left(a_{H}\right)$ set thus consists of the portions of the horizontal and vertical lines passing through $a_{H}$ that offer higher utility to the committees $H$. As drawn, the committees $H$ indifference curve (drawn as a solid line) that is tangent to $p_{H}$ passes just to the left of the point $G$. Thus by choosing amendment $a_{H}$, the minority party forces the committees $H$ to offer the perfecting amendment $p_{H}{ }^{21}$ Similarly, if the committees are located with ideal point $C$, then by offering bill $b_{C}$, the committees force the minority party to offer amendment $a_{C}{ }^{22}$ The minority party's amendment $a_{C}$ forces the committees $C$ to choose $p_{C}$ over a point like $I$ (committees $C$ 's indifference curves are dot-dashed-dot lines).

For either a homogeneous or a non-homogeneous committee, the minority party, by virtue of its amendment-offering status, obtains a policy close to (equal to, as drawn) its preferred policy. The majority party fails to obtain its preferred policy with either committees $H$ or $C$, but it does better with $C$

But, for relatively balanced preferences, $W_{H}(H) \cap W_{H}(q)$ will be quite small.

${ }^{21}$ If the indifference curve tangent to $p_{H}$ passed to the right of $G$, then the amendment $a_{H}$ would have to be pushed up the $\bar{x}_{M}$ loci until the $p_{H}$ point tangent to the $y$ value of $a_{H}$ is such that the committees utility is higher at $p_{H}$ than at $G$.

${ }^{22} \mathrm{We}$ are assuming that due to the institutional restrictions $\chi_{i}, i=M, m$, it is not possible to stack the committees sufficiently to 
than with $H$. Therefore, with extreme party preferences, part of the gains from trade of stacking the committees is attained, and the committees will be classical committee outliers. Interestingly, with an amendment process that favors the minority party, the majority party is most likely to stack the committees, since the amendment process and the preferences of the parties favors the minority party. ${ }^{23}$ Accommodation implies that one committee will be stacked with the left tail of both party distributions and the complement committee will be stacked with the right tail of both party distributions. Thus, not all committee outliers will appear in the same ideological direction.

\section{Confrontation on Committee Assignments.}

Next, consider what happens when one of the parties is extremist, but the other is not. In this case, the extremist party will attempt to skew one committee in the direction it prefers, and this will affect both committees' preferences. The other party is thus forced to confront the extremist party, by stacking its memberships in the opposite direction as the extremist party.

Figure 5 shows what happens when the minority party $m$ is extremist in that it prefers $\bar{y}_{m}$ to any other policy, but the majority party $M$ places equal weight on each policy. In this case, $m$ prefers the equilibrium policy $p_{C}$, obtained with non-homogeneous committees $C$, to the policy $p_{H}$, obtained with homogeneous committees $H \cdot{ }^{24}$ However, the majority party prefers $p_{H}$ to $p_{C}$. Thus, the majority party will stack committee $Y$ to increase $\bar{y}_{C}$, and the minority party will push committee $Y$ back towards $\bar{y}_{f}$. This result also holds when the majority party is the one with strong preferences for a particular committee. Whenever one party has strong preferences for a particular policy, the committee that each party tries to stack will appear to be a bipolar outlier, and the other committee will appear as a bipolar complement. Thus, a bipolar outlier will be stacked with members from the right tail of the Republican party

obtain $C=\left\{\bar{x}_{M}, \bar{y}_{m}\right\}$.

${ }^{23}$ Below in Table 5 we show that this is true empirically. Democrats, who were the majority party, stack thirteen committees with outliers while Republicans stacked only eight committees with outliers.

${ }^{24}$ In this case, the equilibrium amendment process is as follows. Consider the case where the committees are non-homogeneous, with preferred policies $C$. By choosing policy $b_{C}$, the committees force the minority party to offer amendment $a_{C}$. This amendment is chosen such that the committees prefer $p_{C}$ to any element in the upper subsection of $W_{C}(q) \cap W_{C}\left(b_{C}\right) \cap W_{C}\left(a_{C}\right)$. If the committees choose a $b$ closer to $M$, it allows the minority party to obtain a policy more to its liking-and that makes the committees $C$ worse off. A policy $b$ too close to $C$ allows $m$ to choose an amendment on the boundary of the $W_{C}(q)$ that forces $C$ to choose a perfecting amendment to the lower right of $p_{C}$-making $C$ worse off. A similar equilibrium can be derived for $H$. 
distribution and the left tail of the Democratic party distribution. The bipolar complement will be stacked with the left tail of the Republican party distribution and the right tail of the Democratic party distribution.

\section{A Test of the Party Competition Hypothesis}

A test of our hypothesis is available by utilizing the comparative statics presented in Section 3. One way to test the results on the effect of party preferences on how the committees are stacked would be to obtain measures of party preferences utilizing the content of party political advertisements or party platforms. Unfortunately, such data would have to be available for a long enough time period and for enough policies that more than one committee could be included in the analysis. Since such data is not readily available, we searched for an alternative measure.

The U. S. Congress is composed of two houses, the House and the Senate, and each has a separate committee system. Although the committees do not exactly overlap, there is enough of a correspondence that we can observe how the parties stack committees of similar jurisdictions in each house. ${ }^{25}$ Thus for each committee, we use party differences in median between a Senate committee and the Senate party membership to explain the corresponding House difference in median. ${ }^{26}$ The Senate differences in medians are likely to be correlated with party policy preferences but uncorrelated with contemporaneous errors on explaining House party differences in medians (cf., Levitt 1996). Thus the model we estimate is of the form:

$$
H_{c p r t}=\beta_{1} S_{c p r t}+\beta_{2} S_{\tilde{c} p r t}+\beta_{3} S_{c \tilde{p} r t}+\beta_{4} S_{\tilde{c} \tilde{p} r t}+\beta_{5} \hat{x}_{p r t}+\beta_{6} \hat{x}_{\tilde{p} r t}+\varepsilon_{c p r t},
$$

\footnotetext{
${ }^{25}$ In particular, there are sixteen Senate Committees. The correspondence between the House (and Senate) committees are as follows: Agriculture (Agriculture, Nutrition and Forestry); Appropriations (Appropriations); Armed Services (Armed Services); Banking, Finance and Urban Affairs (Banking, Housing and Urban Affairs); Budget (Budget); Education and Labor (Labor and Human Resources); Energy and Commerce (Commerce, Science and Transportation); Foreign Affairs (Foreign Relations); Government Operations (Governmental Affairs); Interior and Insular Affairs (Energy and Natural Resources); Judiciary (Judiciary); Public Works (Environment and Public Works); Rules (Rules and Administration); Small Business (Small Business); Veterans' Affairs (Veterans' Affairs); Ways and Means (Finance).

${ }^{26}$ A referee has pointed out that the Republicans in the Senate are generally given committee assignments based on seniority, rather than being assigned to committees by the party leadership in the manner described in Section 3 . The consistency of our econometric results with the model in which the party leadership makes assignments suggests that the within-party externalities may not be that large, since the laissez faire approach taken in the Senate appears to have similar results to the directed approach taken in the House.
} 
where $H_{c p r t}$ is the difference in median between the House and the committee membership for committee $c$ for party $p$ for rating $r$ in Congress $t ; S_{c p r t}$ is the corresponding Senate difference in median; $S_{\tilde{c} q r t}$ is the mean Senate difference in median for all other committees other than $c$ for party $q=p, \widetilde{p}$; and the $\hat{x}_{q r t}$ are the party median ratings for party $q=p$, $\widetilde{p}$. The hypotheses are that $\beta_{1}>0, \beta_{2}<0, \beta_{3}>0, \beta_{4}<0$, and $\beta_{5}$ and $\beta_{6}$ indeterminate. $\beta_{1}>0$ occurs because as a party's preferences for a particular committee's policy increases, the party will stack that committee more heavily. $\beta_{2}<0$ follows from the notion that if the party stacks some other committee more heavily, it must stack the present committee less so. $\beta_{3}>0$ occurs because as the other party's preferences become more extreme, the party must confront on that committee. $\beta_{4}<0$ because increased confrontation on other committees means less confrontation on this committee. The other variables are included to control for differences in the location (as opposed to the intensity) of party preferences and to control for the relative shares of party memberships.

Table 2 presents ordinary least square estimation results of (7) using the Senate data to explain House committee allocations. The results are presented for the Congress as a whole and for Democrats and Republicans, separately. The first three columns report regressions including only the variables in the table. The last three columns (the "fixed effects model") present regressions including dummy variables for the committees, the ratings, and the Congress.

The model supports the hypotheses regarding how a party will choose to stack a committee based on the weights it and the other party place on different committees. ${ }^{27}$ Both the own party-weights and the other party-weights for the committee have positive coefficients, implying the parties stack committees when their own preferences for the committee's policy increases and when the preferences the other party holds for the committee's policy increases. Interestingly, the own party-weight for Democrats is about half the magnitude as the other party weight, while for Republicans this is reversed. This seems to suggest that Republicans during this time period were stacking committees largely based on their own preferences, while Democrats were paying particular attention to how the Republicans stacked the

\footnotetext{
27 These results appear quite robust. We have sorted them each by rating, by Congress and by committee, and found similar
} 
committees. The own party weights on other committees and the other party weights on other committees each are negative and significant, as predicted.

\section{A Re-Examination of Alternative Hypotheses Tests}

While the tests in Table 1 are supportive of our model, a number of hypotheses appear in the literature for which similar claims have been made. However, most of the previous tests have really been tests of the preference outlier hypothesis - we argue that little space has been devoted to directly testing the committee outlier or the informative committees hypotheses. ${ }^{28}$ In addition, the previous tests have not explicitly controlled for the institutional restrictions. In this section, we provide new tests for each of the competing hypotheses of the organization of Congress.

The null and alternative hypotheses implied by the different Congressional organization hypotheses are given in Table 3. The most common form of hypothesis tests in the preference outlier literature are the difference in medians tests based on interest group ratings, such as those in Table 1. For each standing committee and each interest group rating, we created test statistics for the difference in medians, $d_{p q}=m_{p c}$ $-m_{q f}$, and the ratio of standard deviations, $r_{A A}=s_{A c} s_{A f}$, where $m_{p c}\left(s_{A c}\right)$ is the committee median (standard deviation) for party $p$, and $m_{q f}\left(s_{A f}\right)$ is the floor median (standard deviation) for party $q$, where $p, q=A$ (all members), $D$ (Democratic members only), or $R$ (Republican members only). Each null hypothesis in Table 3 presents the respective hypothesis' concept of a "randomly drawn" committee. Also given is the condition under which each hypothesis would be supported by the evidence. In the informative committees and the representative majority party hypotheses, acceptance of the null hypothesis provides evidence in support of the hypothesis, but in the preference outlier and committee competition hypotheses, the hypothesis is supported if the null hypothesis is rejected. Acceptance of the preference outlier hypothesis implies rejection of the informative committees hypothesis, but it is possible for a

results.

${ }^{28}$ See Weingast and Marshall (1988), Krehbiel (1990), Cox and McCubbins (1993), Mooney and Duval (1993), Groseclose (1994a, 1994b), Londregan and Snyder (1994), and Adler and Lapinski (1997). Both Krehbiel (1990, 1991) and Cox and McCubbins (1993) test the preference outlier theory against the null hypothesis that the committees are a random draw. Only Krehbiel (1991) and Groseclose (1994b) appear to recognize that rejection of the preference outlier hypothesis against the 
committee to not support either hypothesis. Neither the representative majority party hypothesis nor the party competition hypothesis is directly related to the other two hypotheses.

\section{A. The Committee Assignment Algorithm.}

We use a re-sampling method based on empirical distributions of different "permutations" of the committee system in the Congress (e.g., Noreen 1989). ${ }^{29}$ Each permutation of the committee system is a sample drawn without replacement. ${ }^{30}$ This allows us to keep a number of structural characteristics of the Congress intact in our empirical tests. First, each pseudo-committee has the same number of Democratic and Republican members as appear on the actual committee. Second, each member appears on the same distinct number of pseudo-committees as the actual number of committees on which he or she actually sits. Third, each member allocated to a committee has the actual multi-dimensional vector of preferences over different policies held by that individual. ${ }^{31}$ Thus, all committees are formed jointly, and each committee is composed of members with the complete set of attributes of the actual members of the floor, including ratings vectors and number of committee assignments. ${ }^{32}$

For a given test statistic $S \in\left\{d_{p q}, r_{A A}\right\}$ we create a vector of pseudo-test statistics $\left\{S^{b}\right\}$ formed for

random draw hypothesis is not sufficient to accept alternate theories. However, neither of them recognizes that a committee that is more conservative than the floor rejects the random draw hypothesis as well.

${ }^{29}$ The method is similar to the bootstrap technique used by Mooney and Duval (1993) or Groseclose (1994a). However, while the bootstrap method assumes that both the committee and the floor are draws from a given distribution, the permutation method assumes that the floor is the true distribution. Thus the permutation method draws without replacement while the bootstrap draws with replacement, so no member is represented on the same committee more than once. Groseclose (1994b) uses the permutation method but with some differences from our approach as noted below.

${ }^{30}$ The algorithm works as follows: for a particular Congressman, we choose a committee at random. We then check to see if that member is already on the committee or if the party allotment for the committee is full (if so, a new committee is chosen), or if the member is already on his or her full allotment of committees (if so, a new member is chosen). Only when all members have been placed and all committee slots filled is the $b$ th pseudo-committee system formed.If the algorithm failed to form a full committee system (e.g., if a member needs to be placed on one more committee, but all remaining slots are on committees on which he is already a member), the algorithm was instructed to start over with no members placed on any committees. This process ensures that the pseudo-committee system formed is a random draw from the universe of possible committee systems that are valid, given the constraints on committee memberships.

${ }^{31}$ This feature has not been incorporated into other resampling tests in the literature. However, it is consistent with our theoretical model which allows for heterogeneous preferences over multiple policy dimensions. By way of contrast, the bootstrap technique (Mooney and Duval 1993, Groseclose 1994a) implicitly allows some members to serve on a committee more than once. In addition, by forming each committee independently, these authors and Groseclose (1994b) also implicitly assume that each member's ratings vector can be shuffled with other members. Thus, for example, the seat on a committee occupied by Ted Kennedy (a noted liberal) with respect to the ADA rating might be occupied by Jesse Helms (a noted conservative) for the COC rating (cf. Londregan and Snyder 1994).

${ }^{32}$ Groseclose (1994b, p. 447) forms the committees simultaneously on each of the ten committees on which he tests the preference outlier hypothesis. However, he does not appear to control for committee party memberships or for differences in the number of committees on which each member sits, and he does not report whether or not this technique was used in his other hypothesis tests. 
permutation $j=1, \ldots, B$. The statistical tests are based on the empirical distributions of the $S^{b}$ and the observed test statistic $S$. We report the achieved significance level (ASL), a measure of how extreme the test statistic $S$ is. ${ }^{33}$ The ASL's are calculated as $A S L(t)=\min [(n g e+1) /(B+1),(n l e+1) /(B+1)]$, where nge and nle are the number of $S^{b}$ greater than and less than $S$, respectively (Noreen 1989, pp. 14-19). All of our results are based on distributions with $B=2,000 . .^{34}$

A test based on resampling, in which the actual set of committees is compared against many alternative sets that could have been formed, is a natural way to determine whether the dispersion of members across committees can be considered to be due to random assignment or is so unusual that it must be regarded as a consequence of other factors. A parametric test would be more difficult to justify in this context; we cannot assume we have been given a random sample, as required in classical statistics, but instead conduct a test to determine how plausible the assumption of randomness would be.

\section{B. The Preference Outlier, Informative Committees, and Representative Majority Party Hypotheses.}

We present the results of the hypothesis tests using the permutation methodology in Tables 4 and 5 . In each case the test statistic is reported, and test statistics that reject the null hypothesis in a two-tailed test at the $90 \%(*), 95 \%(* *)$ and $99 \%(* * *)$ confidence levels are indicated. ${ }^{35}$ However, in the case of the test on $r_{A A}$ for the informative committees hypothesis, the test is one-tailed because only a smaller committee variance rejects the null hypothesis. We also describe committees as being more "liberal" (more "conservative") if it has a higher (lower) ACLU, ADA, CFA, COPE, or LCV median rating than the House or if it has a lower (higher) COC, NTU, NSI median rating than the House. In discussing the results, a committee is said to reject the null hypothesis only if the null hypothesis is rejected in two or

\footnotetext{
${ }^{33}$ Our results indicate that the sampling without replacement procedure we use gives similar results in terms of variance to the sampling with replacement procedures used by previous authors. The two results are similar because the committee sizes are small relative to the size of the House.

${ }^{34}$ To see if our results were sensitive to the relatively small samples we drew (Groseclose 1994b used 20,000 observations), we reproduced our results for the $97^{\text {th }}$ Congress using 10,000 pseudo-committees, and the ASL results did not change out to four digits in almost all cases, and out to three digits in all cases.

${ }^{35}$ This differs from many previous tests (e.g., Krehbiel 1990, Groseclose 1994b) that are one-sided tests. However, for the reasons mentioned in the theoretical section, there is no reason to believe that all committees will be preference outliers in the same direction. To conduct two-tail tests, we simply calculate whether the observed ASL is less than $1 / 2$ of the critical level, i.e., the ASL is said to be significant at the $1 \%(5 \%)$ [10\%] level if the reported ASL is less than $0.005(0.025)$ [0.05].
} 
more Congresses. ${ }^{36}$

The tests of the preference outlier hypothesis are contained in columns (1)-(6) of Table 4. The preference outlier hypothesis is supported if the null hypothesis of $d_{A A}=0$ is rejected. Eleven of the twenty-two committees favor the preference outlier hypothesis. Eight of these eleven committees are more liberal than the House as a whole (the Appropriations, District of Columbia, Education and Labor, Foreign Affairs, House Administration, Judiciary, Post Office and Civil Service, and Rules committees), but three (the Agriculture, Armed Services, and Veterans Affairs committees) are more conservative than the House as a whole.

The informative committees hypothesis is supported if neither $d_{A A}=0$ nor $r_{A A} \geq 0$ is rejected. This occurs in only eight of the twenty-two committees according to columns (1)-(6) and columns (7)-(12) of Table 4. These committees include the Banking, Finance and Urban Affairs, Budget, Energy and Commerce, Government Operations, Interior and Insular Affairs, Small Business, Standards of Official Conduct, and Ways and Means Committees. A total of eleven committees reject the $d_{A A}=0$ part of the hypothesis and ten committees reject the $r_{A A} \geq 1$ part of the hypothesis. Three committees (the Merchant Marine and Fisheries, the Public Works and Transportation, and the Science, Space and Technology Committees) accept the no difference in medians part of the informative committees hypothesis, but reject the ratio of variance part of the hypothesis.

The tests of the representative-majority-party hypothesis are contained in columns (13)-(18) of Table 4. This hypothesis is supported if the null is not rejected, which occurs in eleven of the twenty-two committees. Interestingly, the set of committees consistent with the representative-majority-party hypothesis is exactly the opposite of the set of committees consistent with the preference outlier hypothesis, and all committees that support the informative committees hypothesis are also consistent with the representative-majority-party hypothesis.

\section{The Party Competition Hypothesis.}

\footnotetext{
${ }^{36}$ This is an ad hoc method, but it is only used to form a basis for discussion. The data in Tables 4 and 5 contains all of the hypothesis tests, so someone disagreeing with our method may construct their own test criteria.
} 
If one takes each of the alternative hypotheses as a method of describing the entire committee system - a point their proponents would undoubtedly argue - then the results in Table 4 do not offer strong support for any of the alternative hypotheses that have been advanced in the literature. According to our statistical tests, these hypotheses can explain at most half the observable committee outcomes.

The party competition hypothesis we have presented in this paper does not offer testable hypotheses with the data used in Table 4. However, our model does offer a simple way in which committees may be categorized. In particular, we expect three general types of committees to appear, depending upon the relative preferences of the parties. When the preferences of each party are unbalanced, accommodation occurs, resulting in preference outlier committees. Not all committees can be preference outliers in the same (liberal or conservative) direction, however, so our model predicts that if preference outliers are observed, some will be in each ideological direction. When the preferences of one party are unbalanced but the preferences of the other party are balanced, we expect that confrontation will occur. This results in bipolar outliers - and our theory predicts these should occur concurrently with bipolar complements. Finally, when the preferences of the parties are relatively balanced, the parties engage in confrontation, but the parties choose committees with members representative of the party.

Table 3 displays hypotheses under which one might identify these three types of committees using difference in medians tests between the party committee membership and the party floor. Accommodation occurs if the null hypothesis in Table 3 is rejected in favor of $\mathrm{H}_{\mathrm{A}}: d_{p p}>0(<0)$ when $d_{q q} \geq 0(\leq 0)$, with $p$ $\neq q=D, R$. Confrontation in the form of bi-polar outliers occurs when the null hypothesis is rejected in favor of $\mathrm{H}_{\mathrm{A}}: d_{D D}>0(<0)$ when $d_{R R}<0(>0)$ for liberal (conservative) ratings, and bipolar outlier complements occurs when the null hypothesis is rejected in favor of $\mathrm{H}_{\mathrm{A}}: d_{D D}>0(<0)$ and $d_{R R}<0(>0)$ for conservative (liberal) ratings. Finally, representative committees, which occur when the parties have similar intensities of preferences, are observed when $d_{D D}=0$ and $d_{R R}=0$.

Reexamining the results of the permutation tests given in Table 5, we see that parties stack committees with non-random members quite frequently. Democrats stack nine committees with more 
liberal members (the Appropriations, District of Columbia, Education and Labor, Energy and Commerce, Foreign Affairs, Interior and Insular Affairs, Judiciary, Post Office and Civil Service, and Rules Committees), but stack four committees with conservative members (the Agriculture, Armed Services, Merchant Marine and Fisheries, and Veterans' Affairs Committees). ${ }^{37,38}$ Republicans stack three committees with more conservative members (the Agriculture, Interior and Insular Affairs, and Veterans Affairs Committees), but stack five committees with more liberal members (the Appropriations, Education and Labor, Merchant Marine and Fisheries, Post Office and Civil Service, and Science, Space and Technology Committees). ${ }^{39}$

Democrats stack thirteen of the twenty-two standing committees, and Republicans stack eight. Fifteen out of the twenty-two standing committees in the House are preference outliers for at least one of the parties. Only seven out of twenty-two committees' memberships are representative of the parties. Accommodation, appearing in thirteen out of the fifteen committees for which at least one party stacks the committee in a non-representative manner, occurs more often than confrontation. However, confrontation, in the form of bipolar outliers, appears to be quite rare. Only the Interior and Insular Affairs Committee appears to be a bipolar outlier, although the Judiciary committee may also fit this description. ${ }^{40}$ The Merchant Marine and Fisheries Committee appears to be a bipolar complement, with both parties stacking the committee with their moderate members. ${ }^{41}$

The pattern of accommodation and confrontation in Table 5 allows one to impute something about the

\footnotetext{
${ }^{37}$ The Public Works and Transportation Committee is an outlier in two Congresses using the NTU rating, but the direction of the difference changes.

${ }^{38}$ From Table 4, by two ratings (LCV and COC), the Energy and Commerce Committee as a whole is stacked with more liberal members in the $97^{\text {th }}$ Congress, which is consistent with results from the Democrats. In addition, for the $97^{\text {th }}$ Congress the Banking, Finance and Urban Affairs Committee is stacked with liberal members of both parties separately and taken together by both the ADA and CFA ratings, and the Public Works and Transportation Committee, which showed inconsistent results with the Democrats, appears as more liberal using the NTU rating for the $97^{\text {th }}$ Congress by all three measures (Democrats only, Republicans only, and the whole committee).

${ }^{39}$ In addition, the Banking, Finance and Urban Affairs Committee appears to be stacked with liberal Republicans in the $97^{\text {th }}$ Congress by both the ADA and CFA ratings.

${ }^{40}$ The Judiciary committee is stacked liberal by Democrats and on the whole committee in more than half of the Congresses. Republicans stack it conservative in the $100^{\text {th }}$ Congress.

${ }^{41}$ Weaker evidence can be found in Table 1 supporting the Science, Space and Technology Committee as also being a bipolar complement (rather than accommodate liberal, as indicated in Table 2). The Republican membership is stacked liberal by the LCV rating in four of the six Congresses, while the Democratic membership and the committee membership as a whole is stacked conservative in two separate Congresses using the ADA rating. The committee median is also not different from the floor.
} 
preferences of the parties over the policies under each committee's jurisdiction. The Democrats appear to have strong preferences for the policies of the Appropriations, District of Columbia, Education and Labor, Energy and Commerce, Foreign Affairs, Judiciary, Post Office and Civil Service, Rules, and Science, Space and Technology committees. The Republicans appear to have strong preferences for the policies for the Agriculture, Armed Services, and Veterans' Affairs committees. Thus on all of these committees, it appears that the intensity of preferences is highly unbalanced. Intensity of preferences appear to be relatively balanced on the Banking, Finance and Urban Affairs, Budget, Government Operations, House Administration, Public Works and Transportation, Small Business, Standards of Official Conduct, and Ways and Means.

\section{Discussion and Conclusions}

Weingast and Marshall (1988), building on earlier work by Niskanen (1971), Shepsle (1979), and others, sparked the debate on the committee outlier hypothesis by suggesting that members of Congress designed the institution for the purpose of ensuring their own reelection success. They argued that the committee system in Congress is perfectly suited to that purpose-it allows members control over policies important to their reelection, and it controls opportunistic behavior by preventing bills unfavorable to the committee from being introduced, which, in turn, helps to enforce logrolling agreements between committees. However, they explicitly assumed that the influence of political parties was negligible. In retrospect, this omission is odd: if the committee system exists to meet its members' reelection needs, does not the party system exist for the same purpose? This paper argues that the answer to that question is 'yes.' Political parties play an important, and empirically supported, role in the organization of the Congress. $^{42}$

Our contribution has been to construct and test a model that predicts how the parties assign seats on

\footnotetext{
${ }^{42}$ A number of authors share our view of the importance of political parties in the workings of the Congress. See Shepsle and Weingast (1994), and the other papers in that volume. Rhode (1994) in particular, shares this view, though he agrees with Krehbiel that the future research "should abandon the view of legislatures as institutions that are overwhelmingly preoccupied with distributive politics" (p. 352, quoting Krehbiel 1991, p. 258). Aldrich (1994) also emphasizes the role of party competition, though he focuses more on how parties participate in the amendment process once a committee bill has been presented to the floor. See also Krehbiel and Meriowitz (1999).
} 
committees. Parties in our model are assumed to have the final word on (new) committee assignments. Since each party wants both to affect party and to get its members reelected, each party member's interests are given positive weight in the party calculus. The party's role is to ensure that opportunistic behavior by some of its members does not cause more damage than those members are worth to the party. However, parties are constrained in what they can and cannot do. Since individual members cannot be removed easily from committees, parties cannot easily discipline members for defecting from the party line. ${ }^{43}$ However, the manner in which the committees are set up in the first place affects how well the system can prevent opportunistic behavior.

Our model is the only existing model capable of generating each of the types of committees observed in the U. S. Congress. Indeed, each of the alternative hypotheses can explain the nature of only about half of the standing committees in the U. S. House of Representatives. Our model has specific predictions regarding how the equilibrium responds to parameters such as the party's policy preferences. Our empirical tests using Senate data as proxies for policy preferences find strong support for our model. In addition, our model predicts that accommodation on one side for one committee means accommodation on the other side for some other committee - a result supported by the data. Similarly, confrontation on one committee resulting in a bipolar outlier implies the existence of a bipolar complement committeeanother result supported by the data.

In conclusion, we support the argument of Weingast and Marshall (1988) and others that the committee system in the Congress is set up to benefit its members' reelection goals. However, we believe that this theory is greatly enriched when the role of parties is recognized as fulfilling a complementary purpose - to ensure the reelection and policy goals of its members by tempering opportunistic behavior via allocations of committee assignments.

\footnotetext{
${ }^{43}$ Indeed, this lack of credible enforcement of the party line is the main reason that Weingast and Marshall assumed party influence to be negligible.
} 
Figure 1: Empirical Distributions of Interest Group Ratings by Party (102 ${ }^{\text {nd }}$ Congress)

ACLU

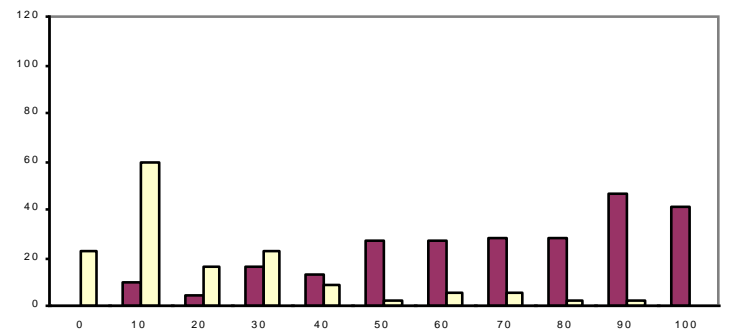

CFA

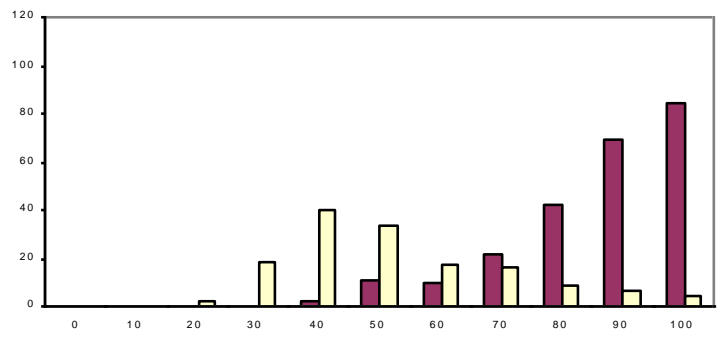

COPE

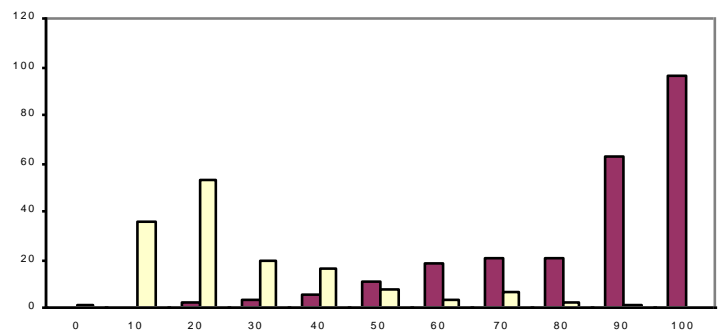

NSI

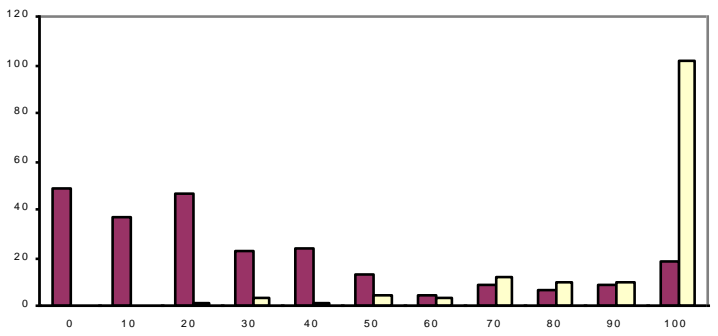

ADA

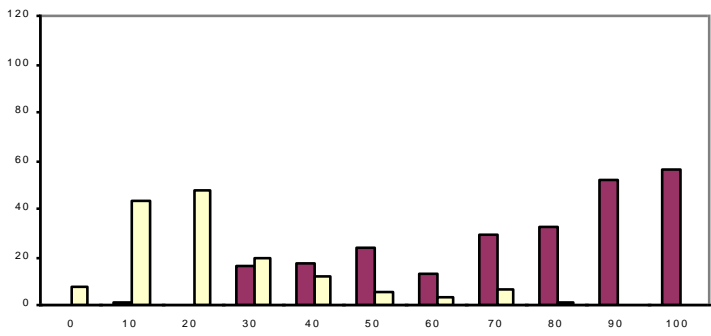

COC

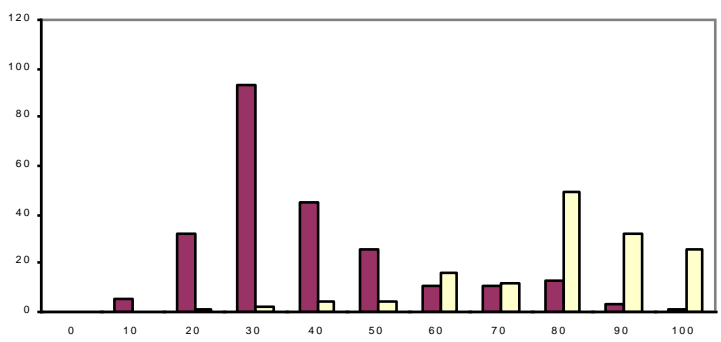

LCV

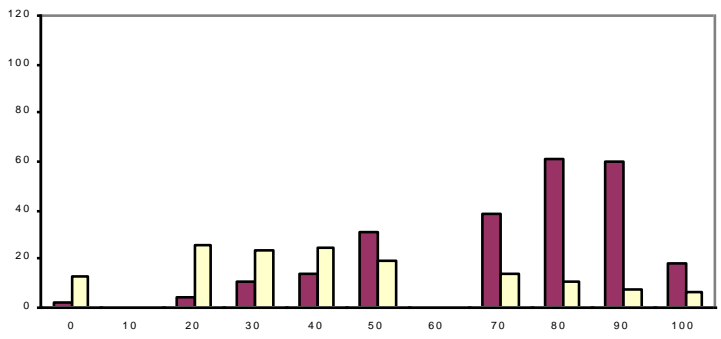

NTLC

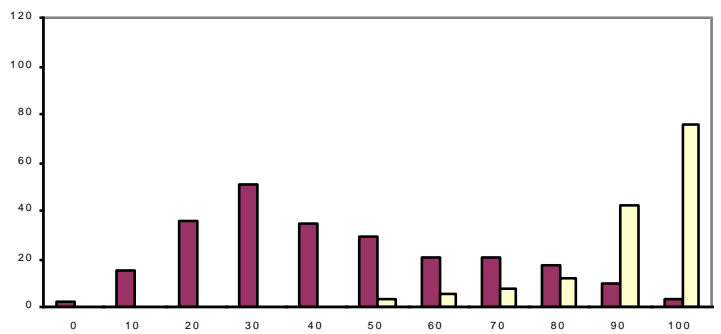

Notes:- Histograms of ratings and by party (Democrats are the dark bars, Republicans the light bars). Each bar represents the number of members with ratings in each range (e.g., the bars at 100 are the number of members with ratings between 91-100, inclusive, and so on; the bar at zero are the number of members with a rating of zero). See Table 1 for a description of the ratings. 
Fig. 2: Structure Induced Equilibrium for $q \notin P S, C \neq H$, and Amendment Procedure $b$ - $a-p$.

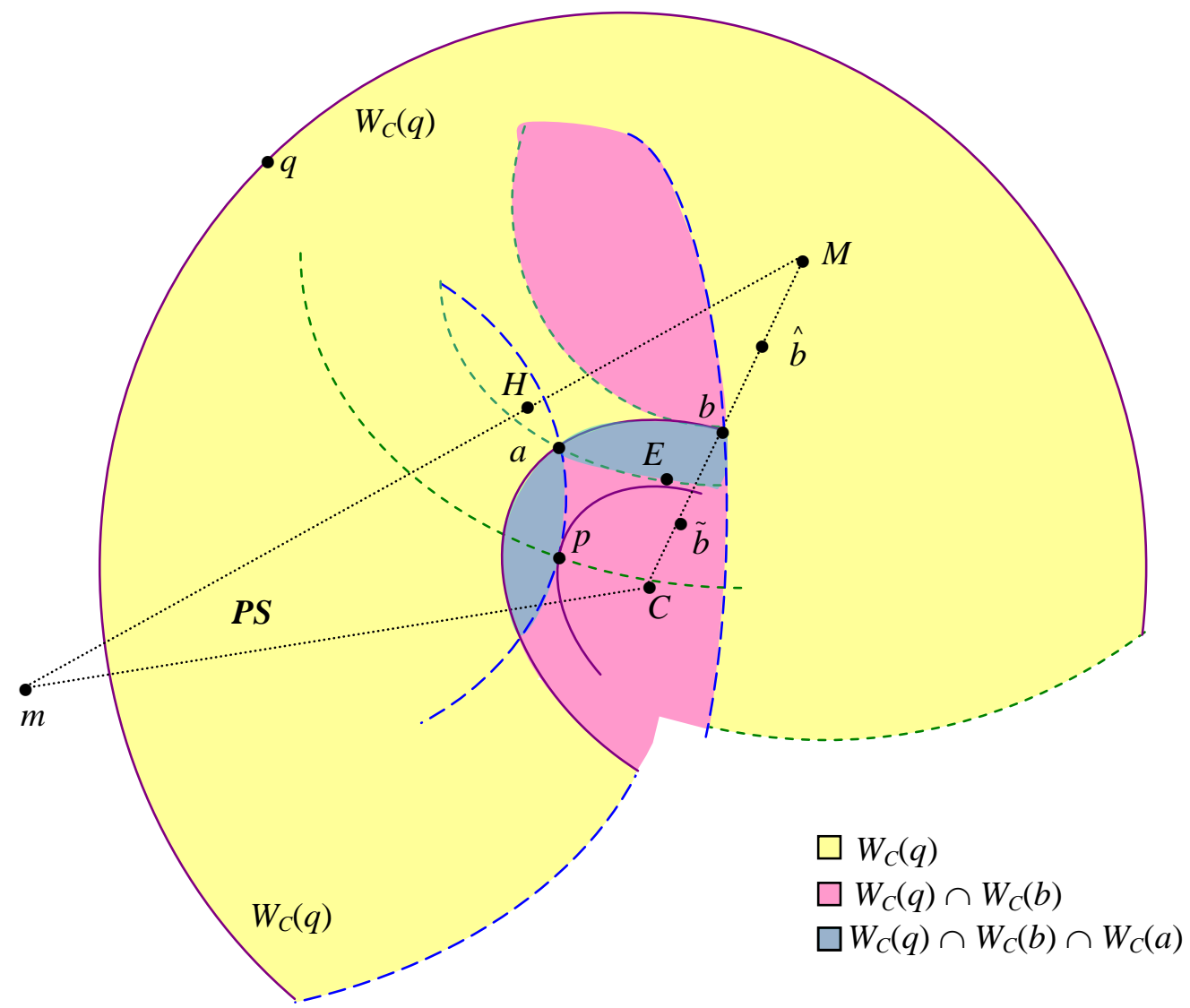


Fig. 3: Structure Induced Equilibrium for $q \in P S, C \neq H$, and Amendment Procedure $b$ - $a$ - $p$.

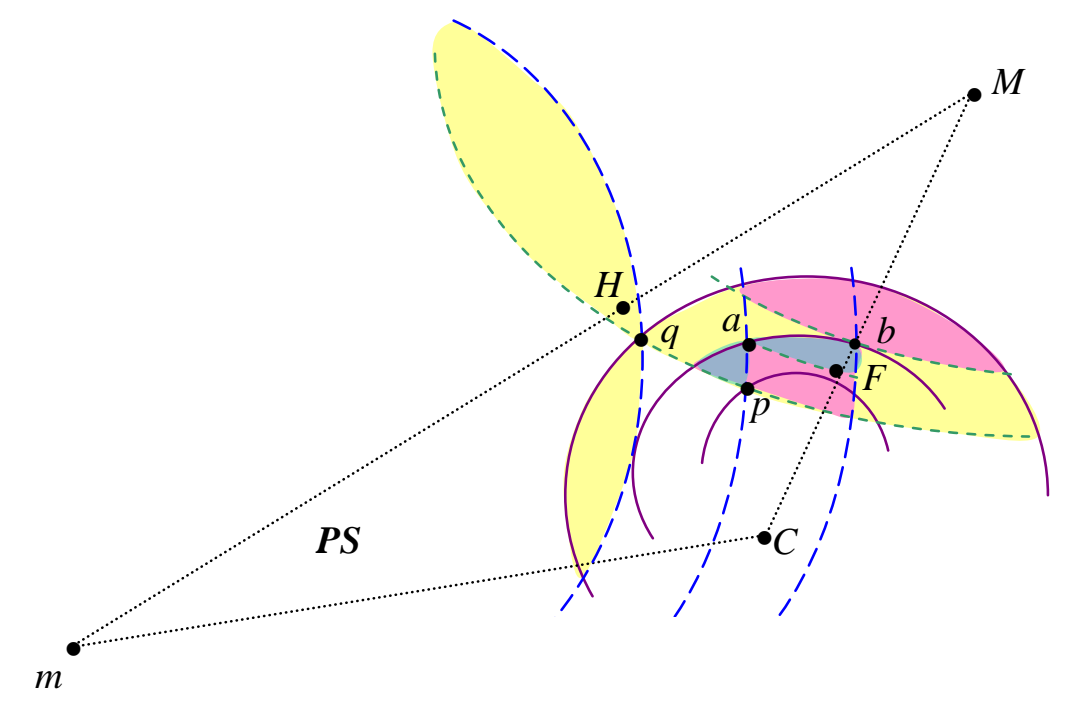

$\square W_{C}(q)$
$\square W_{C}(q) \cap W_{C}(b)$
$\square W_{C}(q) \cap W_{C}(b) \cap W_{C}(a)$


Fig. 4: Structure Induced Equilibrium Committees with Extreme Party Preferences, $q \notin P S$.

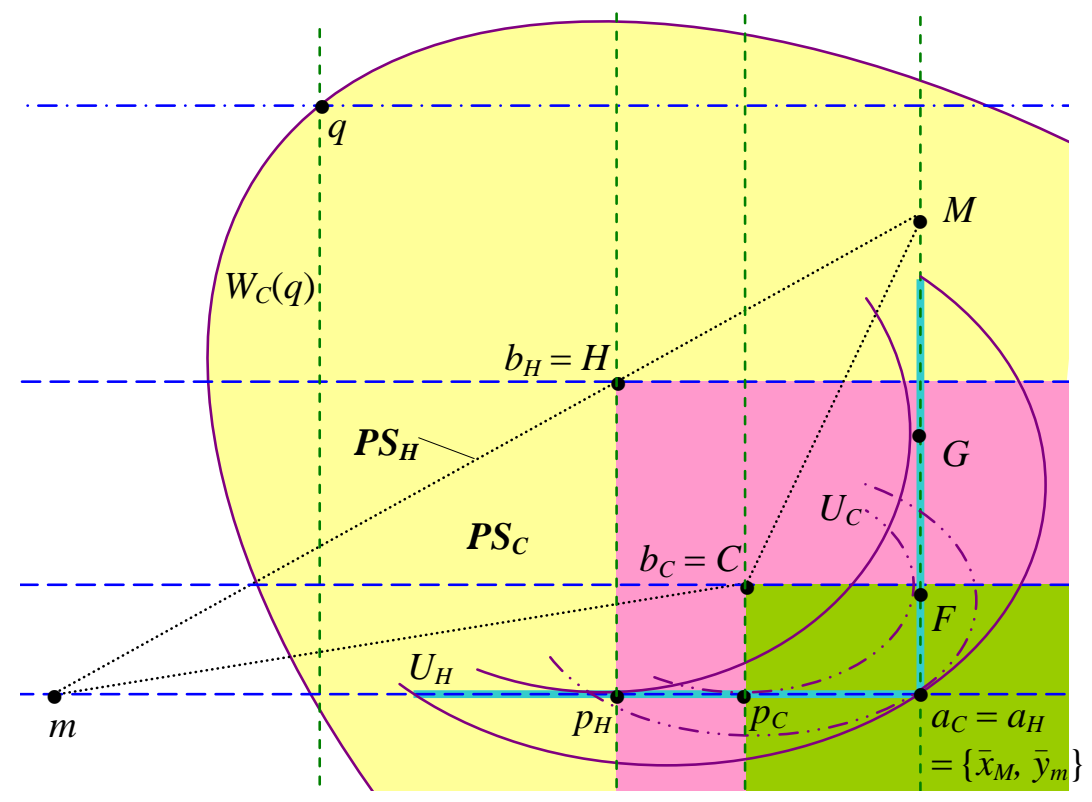
$W_{C}(q)$
$\square W_{H}(q) \cap W_{H}\left(b_{H}\right)$
$\square W_{C}(q) \cap W_{C}\left(b_{C}\right)$
$\square W(q) \cap W\left(b_{C}\right) \cap W\left(a_{C}\right)$ 
Fig. 5: Structure Induced Equilibrium Committees with Extreme Minority Party Preferences.

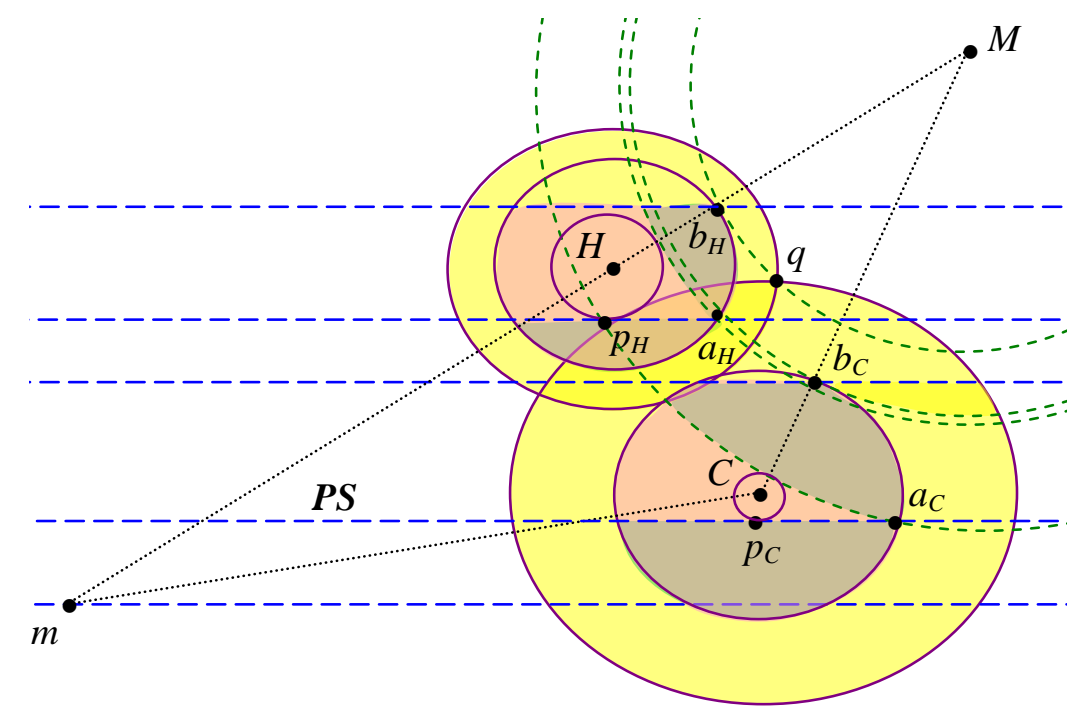

$\square W(q)$

$\square W(q) \cap W(b)$

$\square W(q) \cap W(b) \cap W(a)$ 
Table 1: Median Ratings by Congress by Party

\begin{tabular}{|c|c|c|c|c|c|c|c|c|c|}
\hline \multirow[b]{2}{*}{ Party } & \multirow[b]{2}{*}{ Congress } & \multicolumn{8}{|c|}{ Interest Group Rating } \\
\hline & & ADA & COPE & LCV & CFA & NSI & NTU & $\mathrm{COC}$ & ACLU \\
\hline \multirow[t]{6}{*}{ Whole House } & $97^{\text {th }}$ & 35 & 44 & 45 & 38 & 63 & 35 & 50 & 40 \\
\hline & $98^{\text {th }}$ & 48 & 59 & 62 & 52 & 70 & 41 & 47 & 46 \\
\hline & $99^{\text {th }}$ & 45 & 57 & 58 & 58 & 56 & 32 & 47 & 50 \\
\hline & $100^{\text {th }}$ & 50 & 60 & 53 & 58 & 50 & 33 & 44 & 42 \\
\hline & $101^{\mathrm{st}}$ & 60 & 68 & 56 & 73 & 50 & 29 & 50 & 61 \\
\hline & $102^{\text {nd }}$ & 53 & 67 & 63 & 72 & 50 & 59 & 43 & 48 \\
\hline \multirow[t]{6}{*}{ House Democrats } & $97^{\text {th }}$ & 67 & 72 & 61 & 64 & 33 & 23 & 18 & 53 \\
\hline & $98^{\text {th }}$ & 75 & 83 & 76.5 & 75 & 35.5 & 27 & 33 & 63 \\
\hline & $99^{\text {th }}$ & 75 & 84 & 71 & 75 & 20 & 26 & 38 & 70 \\
\hline & $100^{\text {th }}$ & 75 & 85 & 68 & 75 & 10 & 27 & 28 & 70 \\
\hline & $101^{\text {st }}$ & 80 & 88 & 75 & 82 & 10 & 12 & 36 & 77.5 \\
\hline & $102^{\text {nd }}$ & 78 & 88 & 75 & 89 & 20 & 35 & 29 & 69.5 \\
\hline \multirow[t]{6}{*}{ House Republicans } & $97^{\text {th }}$ & 11 & 16 & 34.5 & 15 & 100 & 56 & 91 & 27 \\
\hline & $98^{\text {th }}$ & 10 & 17 & 30.5 & 23 & 100 & 74 & 77 & 17 \\
\hline & $99^{\text {th }}$ & 10 & 15 & 32 & 25 & 100 & 50.5 & 75 & 15 \\
\hline & $100^{\text {th }}$ & 10 & 16 & 27 & 25 & 100 & 53 & 81 & 10 \\
\hline & $101^{\text {st }}$ & 15 & 17 & 31 & 36 & 100 & 75 & 92 & 26 \\
\hline & $102^{\text {nd }}$ & 11 & 15.5 & 38 & 44 & 100 & 95 & 79 & 9 \\
\hline
\end{tabular}

Notes:- Source: Barone, et al., Almanac of American Politics, various years. The data are the ratings for current members of Congress from the previous Congress (thus newly elected members are excluded). The $97^{\text {th }}$ Congress were elected in November, 1980 and served during 1981-82. The $102^{\text {nd }}$ Congress served during 1991-92. See Table 1 for descriptions of the ratings. 
Table 2: Policy Preferences, Party Power and House Committee Allocations

\begin{tabular}{|c|c|c|c|c|c|c|}
\hline \multirow[b]{2}{*}{ Variable } & \multicolumn{3}{|c|}{ OLS Regressions } & \multicolumn{3}{|c|}{ Fixed Effects Model } \\
\hline & $\begin{array}{r}\text { Whole } \\
\text { Congress } \\
(1)\end{array}$ & $\begin{array}{r}\text { Democrats } \\
(2)\end{array}$ & $\begin{array}{r}\text { Republicans } \\
\text { (3) }\end{array}$ & $\begin{array}{r}\text { Whole } \\
\text { Congress } \\
\text { (4) }\end{array}$ & $\begin{array}{r}\text { Democrats } \\
\text { (5) }\end{array}$ & $\begin{array}{r}\text { Republicans } \\
\text { (6) }\end{array}$ \\
\hline Own Party Weight & $* * * 0.222$ & $* * * 0.072$ & $* * * 0.333$ & $* * * 0.224$ & $* * * 0.071$ & $* * * 0.332$ \\
\hline Same Committee & (11.23) & (3.16) & (10.70) & (11.21) & (3.09) & (10.40) \\
\hline Own Party Weight & $* *-0.176$ & 0.102 & $* * * *_{-} \mathbf{0 . 4 2 8}$ & $* \mathbf{- 0 . 1 4 6}$ & 0.096 & $* * *-0.396$ \\
\hline Other Committees & $(-2.34)$ & $(1.25)$ & $(-3.24)$ & $(-1.80)$ & $(1.02)$ & $(-2.60)$ \\
\hline Other Party Weight & $* * * 0.156$ & $* * * 0.162$ & $* * * 0.148$ & $* * * 0.158$ & $* * * 0.164$ & $* * * 0.151$ \\
\hline Same Committee & (7.86) & (8.18) & (4.19) & (7.91) & $(8.17)$ & (4.17) \\
\hline Other Party Weight & $* * *-0.246$ & $* *-0.176$ & $* *-0.292$ & $* *-\mathbf{0 . 2 0 0}$ & $* *_{-} 0.103$ & $* *-0.342$ \\
\hline Other Committees & $(-3.27)$ & $(-2.11)$ & $(-2.29)$ & $(-2.47)$ & $(-1.08)$ & $(-2.30)$ \\
\hline Own Party’s Floor & $* * *-0.068$ & $* * *_{-} \mathbf{0 . 0 6 2}$ & $* * *-0.073$ & $* * *_{-0} \mathbf{0 . 0 6 9}$ & $*_{-0.048}$ & $*$-0.079 \\
\hline Median & $(-5.53)$ & $(-4.60)$ & $(-2.90)$ & $(-3.28)$ & $(-1.77)$ & $(-1.95)$ \\
\hline Other Party's Floor & $* * *-\mathbf{0 . 0 3 6}$ & $* * \mathbf{0 . 0 3 6}$ & $*_{-\mathbf{0}} \mathbf{0 . 0 3 8}$ & *-0.035 & $* *_{-0.063}$ & $*_{-0.083}$ \\
\hline Median & $(-2.91)$ & $(-2.21)$ & $(-1.78)$ & $(-1.68)$ & $(-2.51)$ & $(-0.19)$ \\
\hline$\overline{\mathrm{R}}^{2}$ & 0.109 & 0.124 & 0.133 & 0.129 & 0.141 & 0.133 \\
\hline$F$-statistic & $* * * 35.318$ & $* * * 20.208$ & $* * * 23.065$ & $* * * 7.941$ & $* * * 5.578$ & $* * * 5.301$ \\
\hline
\end{tabular}

Notes:-Dependent variable is the difference in the party committee median and party floor median by committee, rating, and Congress for the House of Representatives. Data from the $96^{\text {th }}$ to $102^{\text {nd }}$ Congress is used. There are 1,008 observations for each party (nine ratings, seven Congresses, and sixteen committees) and 2,016 for both parties combined. Estimated t-ratios are reported in parentheses. Significance in a two-tail test is indicated by asterisks (***significant at the $1 \%$ level; **significant at the $5 \%$ level; *significant at the $10 \%$ level). All statistically significant results are in bold font. The OLS regressions use the reported variables plus a constant. The fixed effects model regressions include dummy variables for the committees, the ratings, and the Congresses (but no interaction terms). "Own party weight same committee" is the equivalent committee Senate difference in median for the party by rating, by committee, and by Congress. "Own party weight other committees" is the mean of the equivalent committee Senate difference in median for all other committees, by party, by rating, by committee, and by Congress . "Other party weight same committee" and "Other party weight other committees" are constructed similarly for the other party. "Party share in the House" is the party's share of the floor membership by Congress. "Own party median" and "Other party median" are the party floor median by rating and by Congress. 
Table 3: Congressional Organization Hypotheses

\begin{tabular}{|c|c|c|c|}
\hline Hypothesis & Null & Alternative & Criteria to Accept Hypothesis \\
\hline Preference Outlier ${ }^{a}$ & $\mathrm{H}_{0}: d_{A A}=0$ & $\mathrm{H}_{\mathrm{A}}: d_{A A} \neq 0$ & reject $\mathrm{H}_{\mathrm{o}}$ \\
\hline Informative Committees ${ }^{b}$ & $\mathrm{H}_{0}: d_{A A}=0$ and $r_{A A} \geq 1$ & $\mathrm{H}_{\mathrm{A}}:$ Either $d_{A A} \neq 0$ or $r_{A A}<1$ & accept $\mathrm{H}_{\mathrm{o}}$ \\
\hline Representative Majority Party ${ }^{c}$ & $\mathrm{H}_{0}: d_{A D}=0$ & $\mathrm{H}_{\mathrm{A}}: d_{A D} \neq 0$ & accept $\mathrm{H}_{\mathrm{o}}$ \\
\hline $\begin{array}{l}\text { Party Competition: } \\
\text { Accommodation }^{d}\end{array}$ & $\mathrm{H}_{0}: d_{D D}=0 \& d_{R R}=0$ & $\begin{array}{l}\mathrm{H}_{\mathrm{A}}: d_{D D}>0 \& d_{R R}>0, \\
\text { and }^{e} d_{D D}<0 \& d_{R R}<0\end{array}$ & reject $\mathrm{H}_{\mathrm{o}}$ \\
\hline $\begin{array}{l}\text { Party Competition: } \\
\text { Confrontation, Balanced } \\
\text { Intensities of Preferences }\end{array}$ & $\mathrm{H}_{0}: d_{D D}=0 \& d_{R R}=0$ & $\mathrm{H}_{\mathrm{A}}: d_{D D} \neq 0$ or $d_{R R} \neq 0$ & accept $\mathrm{H}_{\mathrm{o}}$ \\
\hline $\begin{array}{l}\text { Party Competition: } \\
\text { Confrontation, Unbalanced } \\
\text { Intensities of Preferences }{ }^{d}\end{array}$ & $\mathrm{H}_{0}: d_{D D}=0 \& d_{R R}=0$ & $\begin{array}{l}\mathrm{H}_{\mathrm{A}}: d_{D D}>0 \& d_{R R}<0, \\
\text { and }^{e} d_{D D}<0 \& d_{R R}>0\end{array}$ & reject $\mathrm{H}_{\mathrm{o}}$ \\
\hline
\end{tabular}

Notes:- ${ }^{a}$ Weingast and Marshall (1988). ${ }^{b}$ Gilligan and Krehbiel (1987, 1989, 1990, 1994), Krehbiel (1990, 1991). ${ }^{c}$ Cox and McCubbins (1993). ${ }^{d}$ The present paper. ${ }^{e}$ The first and second parts of $\mathrm{H}_{\mathrm{A}}$ need to be accepted for different committees for the alternative hypothesis to be accepted. 
Table 4: Tests of Alternative Hypotheses, $97^{\text {th }}-102^{\text {nd }}$ Congress

\begin{tabular}{|c|c|c|c|c|c|c|c|c|c|c|c|c|c|c|c|c|c|c|c|}
\hline \multirow[b]{2}{*}{ Committee } & \multirow[b]{2}{*}{$\begin{array}{r}\text { Congress } \\
\text { Rating } \\
\end{array}$} & \multicolumn{6}{|c|}{$\begin{array}{l}\text { Classical Preference Outlier Hypothesis } \\
\qquad\left(\mathrm{H}_{0}: d_{A A}=0\right)\end{array}$} & \multicolumn{6}{|c|}{$\begin{array}{c}\text { Informative CommitteesHypothesis } \\
\qquad\left(\mathrm{H}_{0}: r_{A A} \geq 1\right)\end{array}$} & \multicolumn{6}{|c|}{$\begin{array}{l}\text { Representative Majority Party Hypothesis } \\
\qquad\left(\mathrm{H}_{0}: d_{A D}=0\right)\end{array}$} \\
\hline & & $\begin{array}{r}9^{\text {th }} \\
(1)\end{array}$ & $\begin{array}{r}\mathbf{9 8}^{\text {th }} \\
(2)\end{array}$ & $\begin{array}{r}99^{\text {th }} \\
\text { (3) }\end{array}$ & $\begin{array}{r}100^{\text {th }} \\
(4)\end{array}$ & $\begin{array}{r}1^{101} 1^{\text {st }} \\
(5)\end{array}$ & $\begin{array}{r}102^{\text {nd }} \\
(6)\end{array}$ & $\begin{array}{r}9^{\text {th }} \\
(7)\end{array}$ & $\begin{array}{r}9^{\text {th }} \\
(8)\end{array}$ & $\begin{array}{r}99^{\text {th }} \\
(9)\end{array}$ & $\begin{array}{r}100^{\text {th }} \\
(10)\end{array}$ & $\begin{array}{r}101^{\text {st }} \\
(11)\end{array}$ & $\begin{array}{r}102^{\text {nd }} \\
(12)\end{array}$ & $\begin{array}{l}\text { 97 }^{\text {th }} \\
(13)\end{array}$ & $\begin{array}{l}\text { 98 }^{\text {th }} \\
(14)\end{array}$ & $\begin{array}{l}9^{\text {th }} \\
(15)\end{array}$ & $\begin{array}{r}100^{\text {th }} \\
(16)\end{array}$ & $\begin{array}{r}\mathbf{1 0 1}^{\text {st }} \\
(17)\end{array}$ & $\begin{array}{r}102^{\text {nd }} \\
(18)\end{array}$ \\
\hline \multirow[t]{3}{*}{ Agriculture } & ADA & -7 & -7.5 & -5 & -12.5 & -10 & -6 & $* 0.92$ & $* * * 0.86$ & $* * * 0.85$ & $* * * 0.86$ & $* * * 0.86$ & $* * * 0.80$ & -39 & -35 & -35 & -37.5 & -30 & -31 \\
\hline & LCV & -6 & -9 & $* *$ *9.5 & $* *-16$ & $*_{-12}$ & $* * *-25$ & 1.11 & 0.99 & 0.96 & $* * 0.88$ & $* 0.90$ & 1.07 & -22 & -23.5 & $* *-23$ & $* *-31$ & $*-31$ & $* * *-37$ \\
\hline & NTU & 1 & 6 & $* * 5$ & $* * 5$ & $* * 13$ & 12 & 0.97 & 0.91 & $* 0.84$ & $* 0.84$ & $* * \mathbf{0 . 9 0}$ & $* * * 0.67$ & 13 & 20 & $* * 11$ & $* * 11$ & $* * 30$ & 36 \\
\hline \multirow[t]{2}{*}{ Appropriations } & ADA & 9 & 0 & 5 & 5 & 5 & 3 & 1.03 & 0.96 & $* 0.93$ & $* 0.93$ & 0.98 & 1.04 & -23 & -27.5 & -25 & -20 & -15 & -22 \\
\hline & NTU & -4.5 & -3.5 & $* * *-5$ & $* * *-6$ & $*_{-12}$ & -9 & $* * \mathbf{0 . 7 8}$ & 0.98 & $* * * 0.77$ & 0.91 & $* * * 0.87$ & 0.84 & 7.5 & 10.5 & $* * * 1$ & $* * * 0$ & $* 5$ & 15 \\
\hline \multirow{2}{*}{ Armed Services } & ADA & $* * *-18$ & $* * *-27.5$ & $* * *-25$ & $* * *-25$ & $* *-12.5$ & $* *-20$ & $* * 0.87$ & $* * 0.87$ & $* * * 0.84$ & $* * * 0.87$ & $* 0.94$ & $* * 0.91$ & $* * *-50$ & $* * *-55$ & $* * *-55$ & $* * *-50$ & $* *-32.5$ & $* *-45$ \\
\hline & NSI & $* * * 37$ & $* * * \mathbf{3 0}$ & $* * * 44$ & $* * * 45$ & $* * * 40$ & $* * 30$ & $* * * 0.81$ & $* * * 0.83$ & $* * * 0.79$ & $* * * 0.84$ & $* * * 0.89$ & $* * 0.93$ & $* * * 67$ & $* * * 64.5$ & $* * * 80$ & $* * * 85$ & $* * * 80$ & $* * 60$ \\
\hline \multirow{3}{*}{$\begin{array}{l}\text { Banking, Finance \& } \\
\text { Urban Affairs }\end{array}$} & ADA & $* 21$ & 15 & 20 & 0 & 10 & -3 & 0.97 & 1.03 & 0.97 & 1.00 & 1.05 & 1.06 & $*_{-11}$ & -12.5 & -10 & -25 & -10 & -28 \\
\hline & CFA & 4.5 & 8 & 0 & 0 & 0 & 0 & 1.00 & 1.04 & 0.96 & 1.01 & 1.02 & 1.08 & -21.5 & -15 & -17 & -17 & -9 & -17 \\
\hline & $\mathrm{COC}$ & -6.5 & 3 & 3 & 6 & 0 & 7 & 0.96 & 1.01 & 1.00 & $* 0.93$ & 0.98 & 1.00 & 25.5 & 17 & 12 & 22 & 14 & 21 \\
\hline \multirow[t]{2}{*}{ Budget } & ADA & 1 & 7.5 & 5 & 5 & -10 & 8.5 & 0.97 & 1.05 & 1.06 & 1.01 & 1.01 & 1.02 & -31 & -20 & -25 & -20 & -30 & -16.5 \\
\hline & NTU & -3.5 & -8 & $* * 6$ & 2.5 & 7.5 & 2 & 0.91 & 1.12 & 1.09 & 1.03 & 1.01 & 0.84 & 8.5 & 6 & $* * 12$ & 8.5 & 24.5 & 26 \\
\hline \multirow[t]{2}{*}{ District of Columbia } & ADA & 37 & 27.5 & $* * 40$ & 15 & **30 & $* * * 41$ & 1.18 & 1.03 & 1.01 & 1.19 & 1.32 & 1.40 & 5 & 0 & $* * 10$ & -10 & $* * 10$ & $* * * 16$ \\
\hline & ACLU & $* * * 33$ & $* * * 46$ & $* * * 37.5$ & $* * 37$ & $* * * 30$ & $* * * 40.5$ & 1.23 & 1.27 & 1.03 & 1.20 & 1.36 & 1.39 & $* * * 20$ & $* * * 29$ & $* * * 17.5$ & $* * 9$ & $* * * 13.5$ & $* * * 19$ \\
\hline \multirow[t]{2}{*}{ Education \& Labor } & ADA & 1 & 20 & $* * 27.5$ & $* * 22.5$ & 10 & $* * 25$ & 1.07 & $* 0.89$ & $* * 0.88$ & $* 0.92$ & 0.94 & 1.00 & -31 & -7.5 & $* *_{-} 2.5$ & $* *-2.5$ & -10 & $* * 0$ \\
\hline & COPE & 3 & $* \mathbf{2 3}$ & $* * * 26$ & $* * 23.5$ & $* * 21$ & $* * * 23$ & 1.06 & 1.03 & 1.05 & 1.03 & 1.11 & 1.08 & -25 & $*_{-1}$ & $* * *-1$ & $* *-1.5$ & $* * 1$ & $* * * 2$ \\
\hline \multirow[t]{3}{*}{ Energy \& Commerce } & ADA & 21 & 15 & 5 & 5 & 0 & 3 & 0.96 & 1.08 & 1.09 & 1.06 & 1.05 & 1.08 & -11 & -12.5 & -25 & -20 & -20 & -22 \\
\hline & LCV & $* * * 22$ & 9 & 9.5 & 2.5 & 0 & 0 & 1.01 & 1.03 & 1.02 & 1.07 & 1.05 & 1.00 & $* * * 6$ & -5.5 & -4 & -12.5 & -19 & -12 \\
\hline & $\mathrm{COC}$ & $* *-28$ & -5 & -3 & 0 & -4 & 3 & 0.99 & 1.08 & 1.02 & 1.09 & 1.02 & 1.11 & $* * 4$ & 9 & 6 & 16 & 10 & 17 \\
\hline \multirow[t]{3}{*}{ Foreign Affairs } & ADA & $* 26$ & 22.5 & 20 & 15 & 15 & $* * 19$ & 0.98 & 0.97 & 1.02 & 1.04 & 0.93 & 1.00 & $*_{-6}$ & -5 & -10 & -10 & -5 & $* *-6$ \\
\hline & NSI & -23 & $* *-33.5$ & $* *-36$ & -25 & $*-30$ & $* *-28$ & 0.98 & 1.03 & 0.98 & 1.00 & 0.98 & 0.96 & 7 & $* * 1$ & $* * 0$ & 15 & $* 10$ & $* * 2$ \\
\hline & LCV & 12.5 & $* * 14$ & $* * * 22.5$ & $* * * 21$ & $* * 19$ & $* * * 25$ & $* 0.90$ & 0.93 & 0.97 & 0.96 & 0.94 & $* * 0.85$ & -3.5 & $* *-0.5$ & $* * * 9$ & $* * * 6$ & $* * \mathbf{0}$ & $* * * 13$ \\
\hline \multirow[t]{2}{*}{ Government Operations } & ADA & -2 & 2.5 & 5 & 20 & 15 & 8 & 1.04 & 0.96 & 1.05 & 0.96 & 1.01 & 0.98 & -34 & -25 & -25 & -5 & -5 & -17 \\
\hline & NTU & -2 & 2 & -2 & -3 & $*_{-13}$ & -3 & 1.02 & $* 0.86$ & 1.11 & 0.91 & 0.98 & 0.95 & 10 & 16 & 4 & 3 & $* 4$ & 21 \\
\hline \multirow[t]{2}{*}{ House Administration } & ADA & 3.5 & 7.5 & 15 & 5 & 2.5 & 8 & 1.08 & 0.91 & 1.06 & 1.07 & 1.03 & 1.03 & -28.5 & -20 & -15 & -20 & -17.5 & -17 \\
\hline & NTU & -8 & $*-14$ & -2 & -3.5 & $*_{-} 16.5$ & $* *-26$ & 1.04 & 1.19 & 1.07 & 1.13 & 1.07 & 0.87 & 4 & $*_{0}$ & 4 & 2.5 & $* 0.5$ & $* *_{-} 2$ \\
\hline
\end{tabular}

Table continued on next page. 
Table 4: (continued)

\begin{tabular}{|c|c|c|c|c|c|c|c|c|c|c|c|c|c|c|c|c|c|c|c|}
\hline \multirow[b]{2}{*}{ Committee } & \multirow[b]{2}{*}{$\begin{array}{l}\text { Congress } \\
\text { Rating }\end{array}$} & \multicolumn{6}{|c|}{$\begin{array}{l}\text { Classical Preference Outlier Hypothesis } \\
\qquad\left(\mathrm{H}_{0}: d_{A A}=0\right)\end{array}$} & \multicolumn{6}{|c|}{$\begin{array}{c}\text { Informative Committees Hypothesis } \\
\qquad\left(\mathrm{H}_{0}: r_{A A} \geq 1\right)\end{array}$} & \multicolumn{6}{|c|}{$\begin{array}{l}\text { Representative Majority Party Hypothesis } \\
\qquad\left(\mathrm{H}_{0}: d_{A D}=0\right)\end{array}$} \\
\hline & & $\begin{array}{r}97^{\text {th }} \\
(1)\end{array}$ & $\begin{array}{r}\mathbf{9 8}^{\text {th }} \\
(2)\end{array}$ & $\begin{array}{r}99^{\text {th }} \\
(3)\end{array}$ & $\begin{array}{r}100^{\text {th }} \\
(4)\end{array}$ & $\begin{array}{r}101^{\text {st }} \\
(5)\end{array}$ & $\begin{array}{r}102^{\text {nd }} \\
(6)\end{array}$ & $\begin{array}{r}9^{\text {th }} \\
(7)\end{array}$ & $\begin{array}{r}\mathbf{9 8}^{\text {th }} \\
(8)\end{array}$ & $\begin{array}{r}9^{\text {th }} \\
(9)\end{array}$ & $\begin{array}{r}\mathbf{1 0 0}^{\text {th }} \\
(10)\end{array}$ & $\begin{array}{r}\mathbf{1 0 1}^{\text {st }} \\
(11)\end{array}$ & $\begin{array}{r}102^{\text {nd }} \\
(12)\end{array}$ & $\begin{array}{l}\text { 97 } \\
(13)\end{array}$ & $\begin{array}{l}\mathbf{9 8}^{\text {th }} \\
(14)\end{array}$ & $\begin{array}{l}9^{\text {th }} \\
(15)\end{array}$ & $\begin{array}{r}\mathbf{1 0 0}^{\text {th }} \\
(16)\end{array}$ & $\begin{array}{r}\mathbf{1 0 1}^{\text {st }} \\
(17)\end{array}$ & $\begin{array}{r}102^{\text {nd }} \\
(18)\end{array}$ \\
\hline \multirow[t]{2}{*}{ Interior \& Insular Affairs } & ADA & 9 & $*-17.5$ & 10 & 15 & 7.5 & 14 & 1.08 & 1.12 & 1.15 & 1.15 & 1.06 & 1.09 & -23 & $*_{-45}$ & -20 & -10 & -12.5 & -11 \\
\hline & $\mathrm{LCV}$ & 7 & -6 & 1 & -5 & 0.5 & 12 & 1.08 & 1.20 & 1.22 & 1.26 & 1.13 & 1.25 & -9 & -20.5 & -12.5 & -20 & -18.5 & 0 \\
\hline \multirow[t]{2}{*}{ Judiciary } & ADA & -2 & $* 22.5$ & 15 & 15 & $* * \mathbf{2 0}$ & $* * 19$ & 1.08 & 1.11 & 1.15 & 1.16 & 1.16 & 1.09 & -34 & $*-5$ & -15 & -10 & $* * 0$ & $* *-6$ \\
\hline & ACLU & 7 & $* * 21$ & $* * * 20$ & 23 & 10 & 10 & 1.10 & 1.19 & 1.16 & 1.15 & 1.12 & 1.07 & -6 & $* * 4$ & $* * * 0$ & -5 & -6.5 & -11.5 \\
\hline \multirow{3}{*}{$\begin{array}{l}\text { Merchant Marine \& } \\
\text { Fisheries }\end{array}$} & $\mathrm{ADA}$ & 9.5 & 7.5 & -2.5 & -10 & -5 & -9 & 0.96 & $* 0.92$ & $* * 0.92$ & $* * * 0.85$ & $* 0.92$ & $* * \mathbf{0 . 9 0}$ & -22.5 & -20 & -32.5 & -35 & -25 & -34 \\
\hline & LCV & 7 & 5.5 & -5 & -4 & -3 & 0 & $* 1.14$ & 0.92 & 1.00 & 0.97 & 0.98 & 1.01 & -9 & -9 & -18.5 & -19 & -22 & -12 \\
\hline & NTU & -5 & -6.5 & 0 & 1 & 5.5 & 8 & 0.87 & $* 0.86$ & 1.04 & $* 0.85$ & $* 0.92$ & 1.73 & 7 & 7.5 & 6 & 7 & 22.5 & 32 \\
\hline \multirow{2}{*}{$\begin{array}{l}\text { Post Office \& Civil } \\
\text { Service }\end{array}$} & ADA & $* 29$ & 20 & $* * * 37.5$ & $* * 27.5$ & $* * 25$ & $* 19.5$ & 1.09 & 1.10 & 1.09 & 0.96 & $* 0.84$ & 0.92 & $*_{-3}$ & -7.5 & $* * * 7.5$ & $* * 2.5$ & $* * 5$ & $*_{-5.5}$ \\
\hline & COPE & $* * * 33$ & $* 19$ & $* * 26.5$ & $* 25.5$ & $* 21$ & $* \mathbf{2 0}$ & 1.20 & 1.12 & 1.00 & 0.92 & $* * 0.78$ & $* 0.87$ & $* * * 5$ & $*-5$ & $* *-0.5$ & $* 0.5$ & $* 1$ & $*-1$ \\
\hline \multirow{2}{*}{$\begin{array}{l}\text { Public Works \& } \\
\text { Transportation }\end{array}$} & ADA & -10 & -2.5 & 7.5 & 0 & 0 & -9 & $* 0.92$ & 0.95 & 1.01 & 1.01 & 1.02 & $* * 0.90$ & -42 & -30 & -22.5 & -25 & -20 & -34 \\
\hline & NTU & 5 & -1.5 & -2.5 & $*-3.5$ & -7 & 4.5 & 1.00 & 0.90 & 0.98 & $* * 0.84$ & 1.04 & $* * 0.77$ & 17 & 12.5 & 3.5 & $* 2.5$ & 10 & 28.5 \\
\hline \multirow{2}{*}{ Rules } & $\mathrm{ADA}$ & 18 & 12.5 & 25 & 15 & 15 & 14 & 0.98 & 1.00 & 1.05 & 1.02 & 0.92 & 1.04 & -14 & -15 & -5 & -10 & -5 & -11 \\
\hline & NTU & $* *-15.5$ & $*-17$ & -4 & -2 & -11 & -21 & 0.93 & 1.21 & 0.85 & 0.80 & 0.95 & 0.91 & $* *-3.5$ & $*-3$ & 2 & 4 & 6 & 3 \\
\hline \multirow[t]{2}{*}{ Small Business } & $\mathrm{ADA}$ & 4 & 5 & -7.5 & -2.5 & 0 & -3 & 0.97 & 0.96 & 1.03 & 0.98 & 1.05 & 1.00 & -28 & -22.5 & -37.5 & -27.5 & -20 & -28 \\
\hline & $\mathrm{COC}$ & 5 & 0 & 1.5 & -2.5 & 6 & 1.5 & 0.98 & 0.93 & 1.04 & 1.12 & 1.01 & 0.97 & 37 & 14 & 10.5 & 13.5 & 20 & 15.5 \\
\hline \multirow{2}{*}{$\begin{array}{l}\text { Standards of Official } \\
\text { Conduct }\end{array}$} & ADA & -10 & -12.5 & -5 & -12.5 & -17.5 & -9 & $* 0.76$ & 1.06 & 1.00 & 1.04 & 1.02 & 1.19 & -42 & -40 & -35 & -37.5 & -37.5 & -34 \\
\hline & ACLU & -10 & -6.5 & -6 & -12 & -8.5 & 9 & 0.84 & 1.22 & 0.99 & 1.08 & 1.07 & 1.22 & -23 & -23.5 & -26 & -40 & -25 & -12.5 \\
\hline \multirow{2}{*}{$\begin{array}{l}\text { Science, Space \& } \\
\text { Technology }\end{array}$} & $\mathrm{ADA}$ & 9.5 & -2.5 & 0 & -5 & 7.5 & $*-11.5$ & 0.93 & $* 0.92$ & $* \mathbf{0 . 9 3}$ & 0.96 & $* 0.94$ & 0.94 & -22.5 & -30 & -30 & -30 & -12.5 & $*-36.5$ \\
\hline & LCV & 8 & 3 & 4.5 & 7 & 7 & -6.5 & 0.93 & 0.94 & $* * * 0.83$ & $* * 0.83$ & $* * * 0.82$ & 1.13 & -8 & -11.5 & -9 & -8 & -12 & -18.5 \\
\hline \multirow[t]{2}{*}{ Veterans' Affairs } & $\mathrm{ADA}$ & -13 & -2.5 & 0 & -12.5 & -5 & -14 & 0.97 & 1.01 & 0.94 & 0.94 & 0.99 & $* * 0.85$ & -45 & -30 & -30 & -37.5 & -25 & -39 \\
\hline & NSI & $* * 26$ & 10 & 22 & 20 & 10 & $* * 40$ & $* 0.89$ & 1.02 & $* 0.94$ & 1.00 & 1.00 & 0.96 & $* * 56$ & 44.5 & 58 & 60 & 50 & $* * 70$ \\
\hline \multirow[t]{2}{*}{ Ways \& Means } & $\mathrm{ADA}$ & 4 & 2.5 & 1 & 0 & 15 & 11 & 0.98 & 1.05 & 0.97 & 1.01 & 0.95 & 1.02 & -28 & -25 & -29 & -25 & -5 & -14 \\
\hline & NTU & 0 & 5 & -0.5 & 1 & -3 & -10 & 0.90 & 1.03 & 1.05 & 1.17 & 1.02 & 0.94 & 12 & 19 & 5.5 & 7 & 14 & 14 \\
\hline
\end{tabular}

Notes:-A positive (negative) sign on the test statistic $d_{A A}$ means the committee median rating is larger (smaller) than the House median rating. The achieved significance levels (ASL) are not reported (they are available from the authors). Significance in a two-tail test (columns 1-6 and columns 13-18) or a one-tail test (columns 7-12) is indicated by asterisks (***significant at the $1 \%$ level; **significant at the $5 \%$ level; *significant at the $10 \%$ level). All statistically significant results are in bold font. See text for a description of the data used in the analysis and a description of the ASL calculations. All tests based on $B=2,000$ permutations. 
Table 5: Difference in Medians Tests by Party, $97^{\text {th }}-102^{\text {nd }}$ Congress

\begin{tabular}{|c|c|c|c|c|c|c|c|c|c|c|c|c|c|c|c|c|}
\hline \multirow[b]{2}{*}{ Committee } & \multirow[b]{2}{*}{$\begin{array}{l}\text { Congress } \\
\text { Rating } \\
\end{array}$} & \multicolumn{6}{|c|}{ Committee Democrats $\left(H_{0}: d_{D D}=0\right)$} & \multicolumn{6}{|c|}{ Committee Republicans $\left(\mathbf{H}_{0}: d_{R R}=\mathbf{0}\right)$} & \multicolumn{3}{|c|}{ Characterization of Committee Type } \\
\hline & & $\begin{array}{r}9^{\text {th }} \\
(1)\end{array}$ & $\begin{array}{r}9^{\text {th }} \\
(2) \\
\end{array}$ & $\begin{array}{r}9^{\text {th }} \\
(3) \\
\end{array}$ & $\begin{array}{r}100^{\text {th }} \\
(4)\end{array}$ & $\begin{array}{r}1^{101^{\text {st }}} \\
(5) \\
\end{array}$ & $\begin{array}{r}102^{\text {nd }} \\
(6) \\
\end{array}$ & $\begin{array}{l}9^{\text {th }} \\
\text { (7) }\end{array}$ & $\begin{array}{r}9^{\text {th }} \\
(8) \\
\end{array}$ & $\begin{array}{r}9^{\text {th }} \\
(9) \\
\end{array}$ & $\begin{array}{r}100^{\text {th }} \\
(10)\end{array}$ & $\begin{array}{r}\mathbf{1 0 1}^{\text {st }} \\
(11) \\
\end{array}$ & $\begin{array}{r}102^{\text {nd }} \\
(12) \\
\end{array}$ & $\begin{array}{c}\text { Democrats } \\
(13)\end{array}$ & $\begin{array}{c}\text { Republicans } \\
\text { (14) }\end{array}$ & $\begin{array}{c}\text { Whole } \\
(15)\end{array}$ \\
\hline Agriculture & $\begin{array}{l}\text { ADA } \\
\text { LCV } \\
\text { NTU }\end{array}$ & $\begin{array}{r}-17 \\
-14 \\
6\end{array}$ & $\begin{array}{l}*-15 \\
*-9.5 \\
* * 11\end{array}$ & $\begin{array}{r}* *-17.5 \\
*-8.5 \\
* * * 5\end{array}$ & $\begin{array}{r}* * \text {-20 } \\
* * *-19 \\
1.5\end{array}$ & $\begin{array}{r}* * * \text {-20 } \\
* * \text {-22 } \\
* * * 14.5\end{array}$ & $\begin{array}{r}* *-22 \\
* * *-25 \\
* * * 27.5\end{array}$ & $\begin{array}{r}* *-1 \\
* *-12.5 \\
2\end{array}$ & $\begin{array}{r}0 \\
-8.5 \\
2\end{array}$ & $\begin{array}{r}5 \\
-1 \\
-3.5\end{array}$ & $\begin{array}{r}0 \\
-6 \\
-3.5\end{array}$ & $\begin{array}{r}-5 \\
0 \\
1\end{array}$ & $\begin{array}{r}-2.5 \\
* *-25 \\
0\end{array}$ & Conservative & Conservative & Accommodate \\
\hline Appropriations & $\begin{array}{l}\text { ADA } \\
\text { NTU }\end{array}$ & $\begin{array}{r}5 \\
-3\end{array}$ & $\begin{array}{r}0 \\
-3\end{array}$ & $\begin{array}{r}0 \\
* * *-5\end{array}$ & $\begin{array}{r}0 \\
* * *-4\end{array}$ & $\begin{array}{r}0 \\
* *-4\end{array}$ & $\begin{array}{r}5 \\
-6\end{array}$ & $\begin{array}{r}0 \\
-3\end{array}$ & $\begin{array}{r}5 \\
-5\end{array}$ & $\begin{array}{r}5 \\
* * *-10\end{array}$ & $\begin{array}{c}2.5 \\
* * \text {-9 }\end{array}$ & $* * \begin{array}{r}2.5 \\
* * 12.5\end{array}$ & $\begin{array}{r}0 \\
* *-9.5\end{array}$ & Liberal & Liberal & Accommodate \\
\hline Armed Services & $\begin{array}{l}\text { ADA } \\
\text { NSI }\end{array}$ & $\begin{array}{r}* * *-45 \\
* * * 51\end{array}$ & $\begin{array}{r}* * *-40 \\
* * * 64.5\end{array}$ & $\begin{array}{l}* * * * 40 \\
* * * 60\end{array}$ & $\begin{array}{r}* * *-30 \\
* * * 60\end{array}$ & $\begin{array}{l}* * * \text {-20 } \\
* * * 50\end{array}$ & $\begin{array}{l}* * * \text {-28 } \\
* * * 30\end{array}$ & $\begin{array}{r}*_{-}^{-0.5} \\
0\end{array}$ & $\begin{array}{r}-5 \\
0\end{array}$ & $\begin{array}{r}-5 \\
0\end{array}$ & $\begin{array}{r}-2.5 \\
0\end{array}$ & $\begin{array}{l}0 \\
0\end{array}$ & $\begin{array}{l}0 \\
0\end{array}$ & Conservative & - & Accommodate \\
\hline $\begin{array}{l}\text { Banking, Finance \& } \\
\text { Urban Affairs }\end{array}$ & $\begin{array}{l}\text { ADA } \\
\text { CFA } \\
\text { COC }\end{array}$ & $\begin{array}{r}5 \\
* * 15 \\
0\end{array}$ & $\begin{array}{l}5 \\
2 \\
0\end{array}$ & $\begin{array}{r}0.5 \\
0 \\
0\end{array}$ & $\begin{array}{l}0 \\
0 \\
1\end{array}$ & $\begin{array}{l}5 \\
0 \\
0\end{array}$ & $\begin{array}{r}5 \\
2.5 \\
0\end{array}$ & $\begin{array}{r}* 14 \\
* 12 \\
-8\end{array}$ & $\begin{array}{r}5 \\
-3 \\
5\end{array}$ & $\begin{array}{r}7.5 \\
4 \\
-5\end{array}$ & $\begin{array}{r}-2.5 \\
-4 \\
-6\end{array}$ & $\begin{array}{r}-5 \\
0 \\
0\end{array}$ & $\begin{array}{l}0 \\
0 \\
0\end{array}$ & - & - & Representative \\
\hline Budget & $\begin{array}{l}\text { ADA } \\
\text { NTU }\end{array}$ & $\begin{array}{r}-3 \\
0.5\end{array}$ & $\begin{array}{l}5 \\
0\end{array}$ & $\begin{array}{r}10 \\
2.5\end{array}$ & $\begin{array}{r}5 \\
1.5\end{array}$ & $\begin{array}{r}5 \\
-0.5\end{array}$ & $\begin{array}{r}5 \\
-2\end{array}$ & $\begin{array}{l}0 \\
3\end{array}$ & $\begin{array}{l}5 \\
9\end{array}$ & $\begin{array}{r}0 \\
7.5\end{array}$ & $\begin{array}{r}-5 \\
2\end{array}$ & $\begin{array}{r}5 \\
-2.5\end{array}$ & $\begin{array}{r}0 \\
-5\end{array}$ & - & - & Representative \\
\hline District of Columbia & $\begin{array}{l}\text { ADA } \\
\text { ACLU }\end{array}$ & $\begin{array}{r}16 \\
* * 22\end{array}$ & $\begin{array}{r}10 \\
* * * 33\end{array}$ & $\begin{array}{r}15 \\
* 20\end{array}$ & $\begin{array}{r}* \mathbf{2 0} \\
19.5\end{array}$ & $\begin{array}{l}* * 17.5 \\
* * * 20\end{array}$ & $\begin{array}{l}* * 22 \\
* * 24\end{array}$ & $\begin{array}{r}0 \\
-0.5\end{array}$ & $\begin{array}{r}3 \\
-0.5\end{array}$ & $\begin{array}{l}5 \\
8\end{array}$ & $\begin{array}{l}-5 \\
-5\end{array}$ & $\begin{array}{l}-5 \\
-9\end{array}$ & $\begin{array}{l}-2.5 \\
-2.5\end{array}$ & Liberal & - & Accommodate \\
\hline Education \& Labor & $\begin{array}{l}\text { ADA } \\
\text { COPE }\end{array}$ & $\begin{array}{r}5 \\
5.5\end{array}$ & $\begin{array}{r}0 \\
* 7\end{array}$ & $\begin{array}{r}10 \\
6\end{array}$ & $\begin{array}{l}5 \\
5\end{array}$ & $\begin{array}{r}* * * 15 \\
* * * 7\end{array}$ & $\begin{array}{r}11 \\
* * * 8\end{array}$ & $\begin{array}{r}0 \\
3.5\end{array}$ & $\begin{array}{r}15 \\
7\end{array}$ & $\begin{array}{r}* * * \mathbf{2 5} \\
2\end{array}$ & $\begin{array}{r}* * \mathbf{1 5} \\
9\end{array}$ & $\begin{array}{r}* * 22.5 \\
6.5\end{array}$ & $\begin{array}{l}* 14 \\
* 10\end{array}$ & Liberal & Liberal & Accommodate \\
\hline Energy \& Commerce & $\begin{array}{l}\text { ADA } \\
\text { LCV } \\
\text { COC }\end{array}$ & $\begin{array}{l}11 \\
10 \\
-7\end{array}$ & $\begin{array}{r}5 \\
* * \mathbf{1 0 . 5} \\
0\end{array}$ & $\begin{array}{r}5 \\
7 \\
-2\end{array}$ & $\begin{array}{r}0 \\
* * 11 \\
0\end{array}$ & $\begin{array}{r}2.5 \\
0 \\
0\end{array}$ & $\begin{array}{l}5 \\
0 \\
0\end{array}$ & $\begin{array}{r}* 17 \\
9.5 \\
-8\end{array}$ & $\begin{array}{r}0 \\
-5.5 \\
4\end{array}$ & $\begin{array}{r}0 \\
-5 \\
-3\end{array}$ & $\begin{array}{r}-5 \\
0 \\
7\end{array}$ & $\begin{array}{r}-5 \\
0 \\
1\end{array}$ & $\begin{array}{r}-2.5 \\
-6.5 \\
6.5\end{array}$ & Liberal & - & Accommodate \\
\hline Foreign Affairs & $\begin{array}{l}\text { ADA } \\
\text { NSI } \\
\text { LCV }\end{array}$ & $\begin{array}{r}11 \\
* *-22.5 \\
10\end{array}$ & $\begin{array}{r}5 \\
-15.5 \\
* 9\end{array}$ & $\begin{array}{r}10 \\
-10 \\
* * * 16\end{array}$ & $\begin{array}{r}* * 12.5 \\
-10 \\
* * 11\end{array}$ & $\begin{array}{r}5 \\
-10 \\
6\end{array}$ & $\begin{array}{r}11 \\
-10 \\
* \mathbf{1 3}\end{array}$ & $\begin{array}{r}* 17 \\
* *-27.5 \\
* * 17.5\end{array}$ & $\begin{array}{r}2.5 \\
0 \\
9.5\end{array}$ & $\begin{array}{r}0 \\
0 \\
11\end{array}$ & $\begin{array}{l}-5 \\
-5 \\
11\end{array}$ & $\begin{array}{r}* 17.5 \\
*-10 \\
10\end{array}$ & $\begin{array}{r}11 \\
* *-20 \\
* * 25\end{array}$ & Liberal & Liberal & Accommodate \\
\hline Government Operations & $\begin{array}{l}\text { ADA } \\
\text { NTU }\end{array}$ & $\begin{array}{l}2.5 \\
4.5\end{array}$ & $\begin{array}{r}-5 \\
3\end{array}$ & $\begin{array}{l}3 \\
2\end{array}$ & $\begin{array}{r}-2.5 \\
1.5\end{array}$ & $\begin{array}{r}7.5 \\
1\end{array}$ & $\begin{array}{r}0 \\
-2\end{array}$ & $\begin{array}{l}6 \\
3\end{array}$ & $\begin{array}{l}7.5 \\
-11\end{array}$ & $\begin{array}{r}0 \\
* 8.5\end{array}$ & $\begin{array}{r}-5 \\
1\end{array}$ & $\begin{array}{r}-5 \\
7.5\end{array}$ & $\begin{array}{r}11 \\
0\end{array}$ & - & - & Representative \\
\hline House Administration & $\begin{array}{l}\text { ADA } \\
\text { NTU }\end{array}$ & $\begin{array}{r}5 \\
-5\end{array}$ & $\begin{array}{r}-7.5 \\
* *-15\end{array}$ & $\begin{array}{r}5 \\
-2.5\end{array}$ & $\begin{array}{r}0 \\
-2\end{array}$ & $\begin{array}{r}2.5 \\
-4\end{array}$ & $\begin{array}{r}5 \\
-11\end{array}$ & $\begin{array}{l}0 \\
3\end{array}$ & $\begin{array}{r}-5 \\
3\end{array}$ & $\begin{array}{r}0 \\
1.5\end{array}$ & $\begin{array}{r}-10 \\
3\end{array}$ & $\begin{array}{r}-5 \\
2.5\end{array}$ & $\begin{array}{l}-2.5 \\
-9.5\end{array}$ & - & - & Representative \\
\hline
\end{tabular}

Table continued on next page. 
Table 5: (continued)

\begin{tabular}{|c|c|c|c|c|c|c|c|c|c|c|c|c|c|c|c|c|}
\hline \multirow[b]{2}{*}{ Committee } & \multirow[b]{2}{*}{$\begin{array}{r}\text { Congress } \\
\text { Rating } \\
\end{array}$} & \multicolumn{6}{|c|}{ Committee Democrats $\left(\mathrm{H}_{0}: d_{D D}=0\right)$} & \multicolumn{6}{|c|}{ Committee Republicans $\left(\mathbf{H}_{0}: d_{R R}=\mathbf{0}\right)$} & \multicolumn{3}{|c|}{ Characterization of Committee Type } \\
\hline & & $\begin{array}{r}97^{\text {th }} \\
(1) \\
\end{array}$ & $\begin{array}{r}\mathbf{9 8}^{\text {th }} \\
(2)\end{array}$ & $\begin{array}{r}\mathbf{9 9}^{\text {th }} \\
(3)\end{array}$ & $\begin{array}{r}100^{\text {th }} \\
(4) \\
\end{array}$ & $\begin{array}{r}101^{\text {st }} \\
(5) \\
\end{array}$ & $\begin{array}{r}102^{\text {nd }} \\
(6) \\
\end{array}$ & $\begin{array}{l}9^{\text {th }} \\
\text { (7) }\end{array}$ & $\begin{array}{r}\mathbf{9 8}^{\text {th }} \\
(8) \\
\end{array}$ & $\begin{array}{r}\mathbf{9 9}^{\text {th }} \\
(9) \\
\end{array}$ & $\begin{array}{r}\text { 100 }^{\text {th }} \\
(10)\end{array}$ & $\begin{array}{r}\text { 101 }^{\text {st }} \\
(11)\end{array}$ & $\begin{array}{r}102^{\text {nd }} \\
(12) \\
\end{array}$ & $\begin{array}{c}\text { Democrats } \\
(13)\end{array}$ & $\begin{array}{c}\text { Republicans } \\
\text { (14) }\end{array}$ & $\begin{array}{c}\text { Whole } \\
\text { (15) }\end{array}$ \\
\hline Interior \& Insular Affairs & $\begin{array}{l}\text { ADA } \\
\text { LCV }\end{array}$ & $\begin{array}{r}5 \\
* * 17\end{array}$ & $\begin{array}{r}* 10 \\
4.5\end{array}$ & $\begin{array}{r}10 \\
* * 15\end{array}$ & $\begin{array}{r}10 \\
7.5\end{array}$ & $\begin{array}{l}0 \\
0\end{array}$ & $\begin{array}{r}5 \\
6.5\end{array}$ & $\begin{array}{r}5 \\
-1\end{array}$ & $\begin{array}{r}0 \\
* * *-16\end{array}$ & $\begin{array}{r}-5 \\
*-11\end{array}$ & $\begin{array}{r}-5 \\
*-11\end{array}$ & $\begin{array}{r}-5 \\
-12\end{array}$ & $\begin{array}{r}0 \\
*-25\end{array}$ & Liberal & Conservative & Bipolar Outlier \\
\hline Judiciary & $\begin{array}{r}\text { ADA } \\
\text { ACLU }\end{array}$ & $\begin{array}{l}0 \\
2\end{array}$ & $\begin{array}{r}10 \\
* * * 22\end{array}$ & $\begin{array}{r}10 \\
* \mathbf{1 5}\end{array}$ & $\begin{array}{r}7.5 \\
* * 19\end{array}$ & $\begin{array}{r}10 \\
6.5\end{array}$ & $\begin{array}{r}5 \\
12.5\end{array}$ & $\begin{array}{l}3 \\
0\end{array}$ & $\begin{array}{r}0 \\
-7\end{array}$ & $\begin{array}{r}-2.5 \\
-1\end{array}$ & $\begin{array}{r}*-10 \\
-5\end{array}$ & $\begin{array}{r}-5 \\
-12\end{array}$ & $\begin{array}{l}0 \\
2\end{array}$ & Liberal & - & Bipolar Outlier \\
\hline $\begin{array}{l}\text { Merchant Marine \& } \\
\text { Fisheries }\end{array}$ & $\begin{array}{l}\text { ADA } \\
\text { LCV } \\
\text { NTU }\end{array}$ & $\begin{array}{r}-6 \\
6 \\
0.5\end{array}$ & $\begin{array}{r}-10 \\
-3.5 \\
2\end{array}$ & $\begin{array}{r}-10 \\
-8 \\
0\end{array}$ & $\begin{array}{r}*-15 \\
-3.5 \\
3.5\end{array}$ & $\begin{array}{r}*-7.5 \\
-6 \\
* 7.5\end{array}$ & $\begin{array}{r}*-17 \\
0 \\
10\end{array}$ & $\begin{array}{r}* * * 28 \\
-2 \\
* *-13\end{array}$ & $\begin{array}{r}0 \\
2.5 \\
* *-18\end{array}$ & $\begin{array}{r}5 \\
-7 \\
*-7.5\end{array}$ & $\begin{array}{r}* 10 \\
1 \\
*-8\end{array}$ & $\begin{array}{r}7.5 \\
0 \\
-4.5\end{array}$ & $\begin{array}{r}6 \\
12 \\
0\end{array}$ & Conservative & Liberal & $\begin{array}{l}\text { Bipolar } \\
\text { Complement }\end{array}$ \\
\hline $\begin{array}{l}\text { Post Office \& Civil } \\
\text { Service }\end{array}$ & $\begin{array}{l}\text { ADA } \\
\text { COPE }\end{array}$ & ****17 & $\begin{array}{r}5 \\
* * * 9\end{array}$ & $\begin{array}{r}* 12.5 \\
* * * 11\end{array}$ & $\begin{array}{r}10 \\
* * 8\end{array}$ & $\begin{array}{r}10 \\
* * * 6.5\end{array}$ & $\begin{array}{r}11 \\
* 5.5\end{array}$ & $\begin{array}{r}0 \\
-1\end{array}$ & $\begin{array}{l}-5 \\
-4\end{array}$ & $\begin{array}{l}2.5 \\
5.5\end{array}$ & $\begin{array}{l}10 \\
12\end{array}$ & $\begin{array}{l}* * 35 \\
* * 40\end{array}$ & $\begin{array}{r}* 19.5 \\
* * * 34\end{array}$ & Liberal & Liberal & Accommodate \\
\hline $\begin{array}{l}\text { Public Works \& } \\
\text { Transportation }\end{array}$ & $\begin{array}{l}\text { ADA } \\
\text { NTU }\end{array}$ & $\begin{array}{r}-11 \\
-1\end{array}$ & $\begin{array}{r}-5 \\
0\end{array}$ & $\begin{array}{l}0 \\
1\end{array}$ & $\begin{array}{r}0 \\
* *-2.5\end{array}$ & $\begin{array}{l}0 \\
0\end{array}$ & $\begin{array}{l}-11 \\
* 13\end{array}$ & $\begin{array}{l}0 \\
0\end{array}$ & $\begin{array}{r}0 \\
-1\end{array}$ & $\begin{array}{r}5 \\
-6.5\end{array}$ & $\begin{array}{r}-2.5 \\
* *-10\end{array}$ & $\begin{array}{r}-5 \\
2\end{array}$ & $\begin{array}{l}0 \\
0\end{array}$ & - & - & Representative \\
\hline Rules & $\begin{array}{l}\text { ADA } \\
\text { NTU }\end{array}$ & $\begin{array}{r}5 \\
*-8\end{array}$ & $\begin{array}{r}-5 \\
* *-16\end{array}$ & $\begin{array}{r}0 \\
-2\end{array}$ & $\begin{array}{l}0 \\
1\end{array}$ & $\begin{array}{l}5 \\
5\end{array}$ & $\begin{array}{r}0 \\
-10\end{array}$ & $\begin{array}{r}0 \\
-1\end{array}$ & $\begin{array}{r}-2.5 \\
7\end{array}$ & $\begin{array}{r}-2.5 \\
-4\end{array}$ & $\begin{array}{r}-5 \\
-4.5\end{array}$ & $\begin{array}{r}7.5 \\
-8\end{array}$ & $\begin{array}{r}0.5 \\
-2.5\end{array}$ & Liberal & - & Accommodate \\
\hline Small Business & $\begin{array}{l}\mathrm{ADA} \\
\mathrm{COC}\end{array}$ & $\begin{array}{r}5 \\
-4\end{array}$ & $\begin{array}{r}-2.5 \\
4\end{array}$ & $\begin{array}{l}0 \\
0\end{array}$ & $\begin{array}{l}-5 \\
-3\end{array}$ & $\begin{array}{r}0 \\
* 7\end{array}$ & $\begin{array}{l}0 \\
0\end{array}$ & $\begin{array}{r}7.5 \\
-18\end{array}$ & $\begin{array}{r}2.5 \\
-5.5\end{array}$ & $\begin{array}{l}0 \\
3\end{array}$ & $\begin{array}{r}-5 \\
* * 13\end{array}$ & $\begin{array}{r}-7.5 \\
1\end{array}$ & $\begin{array}{l}0 \\
0\end{array}$ & - & - & Representative \\
\hline $\begin{array}{l}\text { Standards of Official } \\
\text { Conduct }\end{array}$ & $\begin{array}{l}\text { ADA } \\
\text { ACLU }\end{array}$ & $\begin{array}{l}-20 \\
-18\end{array}$ & $\begin{array}{r}7.5 \\
20\end{array}$ & $\begin{array}{r}0 \\
-2.5\end{array}$ & $\begin{array}{r}5 \\
7.5\end{array}$ & $\begin{array}{r}5 \\
9.5\end{array}$ & $\begin{array}{r}16 \\
* * 21.5\end{array}$ & $\begin{array}{l}4.5 \\
1.5\end{array}$ & $\begin{array}{r}2.5 \\
-6.5\end{array}$ & $\begin{array}{r}2.5 \\
0\end{array}$ & $\begin{array}{r}-5 \\
-2.5\end{array}$ & $\begin{array}{r}7.5 \\
5\end{array}$ & $\begin{array}{r}6 \\
-0.5\end{array}$ & - & - & Representative \\
\hline $\begin{array}{l}\text { Science, Space \& } \\
\text { Technology }\end{array}$ & $\begin{array}{l}\text { ADA } \\
\text { LCV }\end{array}$ & $\begin{array}{l}-6.5 \\
-5.5\end{array}$ & $\begin{array}{r}-5 \\
-2.5\end{array}$ & $\begin{array}{l}-5 \\
-7\end{array}$ & $\begin{array}{r}* *-12.5 \\
-6.5\end{array}$ & $\begin{array}{r}-2.5 \\
-6\end{array}$ & $\begin{array}{r}-8.5 \\
-12\end{array}$ & $\begin{array}{r}14 \\
* \mathbf{1 3 . 5}\end{array}$ & $\begin{array}{r}5 \\
4.5\end{array}$ & $\begin{array}{r}5 \\
* 16\end{array}$ & $\begin{array}{r}0 \\
* * * 21\end{array}$ & $\begin{array}{r}0 \\
* * 19\end{array}$ & $\begin{array}{r}0 \\
-6.5\end{array}$ & - & Liberal & $\begin{array}{c}\text { Bipolar } \\
\text { Complement }\end{array}$ \\
\hline Veterans' Affairs & $\begin{array}{l}\text { ADA } \\
\text { NSI }\end{array}$ & $\begin{array}{l}* *-34 \\
* * * 56\end{array}$ & $\begin{array}{r}-10 \\
4.5\end{array}$ & $\begin{array}{r}*-15 \\
5\end{array}$ & $\begin{array}{r}-10 \\
10\end{array}$ & $\begin{array}{l}-5 \\
10\end{array}$ & $\begin{array}{r}* *_{-25} \\
* 20\end{array}$ & $\begin{array}{r}0 \\
-11\end{array}$ & $\begin{array}{l}0 \\
0\end{array}$ & $\begin{array}{r}5 \\
-10\end{array}$ & $\begin{array}{r}-5 \\
0\end{array}$ & $\begin{array}{l}5 \\
0\end{array}$ & $\begin{array}{l}6 \\
0\end{array}$ & Conservative & - & Accommodate \\
\hline Ways \& Means & $\begin{array}{l}\text { ADA } \\
\text { NTU }\end{array}$ & $\begin{array}{r}-17 \\
1\end{array}$ & $\begin{array}{r}5 \\
-2\end{array}$ & $\begin{array}{r}0 \\
-1\end{array}$ & $\begin{array}{l}0 \\
1\end{array}$ & $\begin{array}{l}0 \\
2\end{array}$ & $\begin{array}{r}5 \\
*-10\end{array}$ & $\begin{array}{l}0 \\
1\end{array}$ & $\begin{array}{r}-2.5 \\
8.5\end{array}$ & $\begin{array}{r}0 \\
0.5\end{array}$ & $\begin{array}{l}0 \\
6\end{array}$ & $\begin{array}{r}12.5 \\
0.5\end{array}$ & $\begin{array}{r}0 \\
-5\end{array}$ & - & - & Representative \\
\hline
\end{tabular}

Notes:- See notes to Table 1. The difference in medians tests are labeled "Liberal" ("Conservative") if the ACLU, ADA, CFA, COPE, or LCV difference in medians tests are significantly positive (negative) in two or more of the six Congresses, or if the ACU, COC, NSI, or NTU difference in medians tests are significantly negative (positive) in two or more of the six Congresses. ("Conservative/Liberal" means the tests yielded both results with different ratings or different Congresses.) For each of the hypotheses, "--" indicates acceptance of $\mathrm{H}_{0}$. Significance in a two-tail test is indicated by asterisks (***significant at the $1 \%$ level; **significant at the $5 \%$ level; *significant at the $10 \%$ level). All statistically significant results are in bold font. 


\section{References}

Adler, E. Scott, and John S. Lapinski (1997), "Demand-Side Theory and Congressional Committee Composition: A Constituency Characteristics Approach," American Journal of Political Science, 41: 895-918.

Aldrich, John H. (1994), "A Model of a Legislature with Two Parties and a Committee System," Legislative Studies Quarterly, XIX: 313-39.

Barone, Michael, et al. (1981, 1983, 1985, 1987, 1989, 1991), Almanac of American Politics, National Journal: Washington, D.C.

Benson, Bruce L. (1981), "Why Are Congressional Committees Dominated by 'High-Demand' Legislators?-A Comment on Niskanen's View of Bureaucrats and Politicians," Southern Journal of Economics, 48: 68-77.

Benson, Bruce L. (1983), "Logrolling and High Demand Committee Review,” Public Choice, 45: 427434.

Cox, Gary W., and Mathew D. McCubbins (1993), Legislative Leviathan: Party Government in the House, University of California Press: Berkeley.

Epstein, David (1997), “An Informational Rationale for Committee Gatekeeping Power," Public Choice 91: 271-99.

Gilligan, Thomas W., and Keith Krehbiel (1987), "Collective Decision-Making and Standing Committees: An Informational Rationale for Restrictive Amendment Procedures," Journal of Law, Economics, and Organization, 3: 287-335.

Gilligan, Thomas W., and Keith Krehbiel (1989), "Asymmetric Information and Legislative Rules with a Heterogeneous Committee," American Journal of Political Science, 33: 459-90.

Gilligan, Thomas W., and Keith Krehbiel (1990), "Organization of Informative Committees by a Rational Legislature," American Journal of Political Science, 34: 531-64.

Gilligan, Thomas W., and Keith Krehbiel (1994), "The Gains from Exchange Hypothesis of Legislative Organization,” Legislative Studies Quarterly, XIX: 181-214.

Groseclose, Tim (1994a), "The Committee Outlier Debate: A Review and Reexamination of Some of the Evidence," Public Choice, 80: 265-73.

Groseclose, Tim (1994b), "Testing Committee Composition Hypotheses for the U. S. Congress," Journal of Politics, 56: 440-58.

Hall, Richard L., and Bernard Grofman (1990), "The Committee Assignment Process and the Conditional Nature of Committee Bias,” American Political Science Review, 84: 1149-1166.

Kern, Montague (1989), 30-Second Politics: Political Advertising in the Eighties, Praeger: New York.

Krehbiel, Keith (1997), “Are Congressional Committees Composed of Preference Outliers?” American Journal of Political Science, 84, 149-63.

Krehbiel, Keith (1990), "Restrictive Rules Reconsidered," American Political Science Review, 41: 91944.

Krehbiel, Keith (1991), Information and Legislative Organization, The University of Michigan Press: Ann Arbor.

Krehbiel, Keith, and Adam Meirowitz (1999), "Parliamentary Rights and Party Power," mimeo, Graduate School of Business, Stanford University. 
Londregan, John, and James M. Snyder, Jr. (1994), "Comparing Committee and Floor Preferences," Legislative Studies Quarterly, XIX: 233-66.

Maltzman, Forrest (1995), "Meeting Competing Demands: Committee Performance in the Postreform House," American Journal of Political Science, 39: 653-82.

McKelvey, Richard D. (1976), "Intransitivities in Multidimensional Voting Models and Some Implications for Agenda Control," Journal of Economic Theory, 12: 472-82.

Mooney, Christopher Z., and Robert D. Duval (1993), Bootstrapping: A Nonparametric Approach to Statistical Inference, Sage Publications: Newbury Park.

Niskanen, William A. (1971), Bureaucracy and Representative Government, Aldine-Atherton Press: Chicago.

Noreen, Eric W. (1989), Computer Intensive Methods for Testing Hypotheses, John Wiley and Sons: New York.

Philipson, Tomas (1992), "The Exchange and Allocation of Decision Power," Decision and Theory, 33: 191-206.

Plott, Charles (1967), "A Notion of Equilibrium and Its Possibility Under Majority Rule," American Economic Review, 57: 787-806.

Rhode, David W. (1994), "Parties and Committees in the House: Member Motivations, Issues, and Institutional Arrangements," Legislative Studies Quarterly, XIX: 341-59.

Riker, William (1980), "Implications from the Disequilibrium of Majority Rule for the Study of Institutions," American Political Science Review, 73: 85-102.

Saving, Jason L. (1997), "Human Capital, Committee Power and Legislative Outcomes," Public Choice, 92: 301-16.

Shepsle, Kenneth A. (1979), "Institutional Arrangements and Equilibrium in Multidimensional Voting Models," American Journal of Political Science, 23: 27-59.

Stratmann, Thomas (1996), "How Reelection Constituencies Matter: Evidence from Political Action Committees' Contributions and Congressional Voting," Journal of Law and Economics, XXXIX: 603-635.

Shepsle, Kenneth A., and Barry R. Weingast (1994), "Positive Theories of Congressional Institutions," Legislative Studies Quarterly, XIX: 149-79.

Weingast, Barry R. (1989), "Floor Behavior in the U. S. Congress: Committee Power under an Open Rule," American Political Science Review, 83: 795-815.

Weingast, Barry R., and William Marshall (1988), "The Industrial Organization of Congress: Or Why Legislatures, Like Firms, are Not Organized as Markets," Journal of Political Economy, 96: 132-63. 